\title{
Drift sands, lakes, and soils: the multiphase Holocene history of the Laarder Wasmeren area near Hilversum, the Netherlands
}

\author{
J. Sevink ${ }^{1,}{ }^{*}$, E.A. Koster ${ }^{2}$, B. van Geel ${ }^{1} \&$ J. Wallinga ${ }^{3}$
}

1 Institute for Biodiversity and Ecosystem Dynamics (IBED), University of Amsterdam, the Netherlands

2 Department of Physical Geography, Faculty of Geosciences, Utrecht University, the Netherlands

3 Soil Geography and Landscape group, Wageningen University / Netherlands Centre for Luminescence dating (NCL), Delft University of Technology, the Netherlands

* Corresponding author. Email: j.sevink@uva.nl

Manuscript received: August 2012, accepted: April 2013

\section{Abstract}

A unique complex of multiphased Holocene drift sands and paleosols, with at least two lacustrine phases, was discovered during a major sanitation project in the Laarder Wasmeren area near Hilversum, the Netherlands. The complex could be studied in detail, highly facilitated by the excellent and large-scale exposure of the various deposits and soils. OSL dating was used to establish ages of the phases, where possible differentiating between time of deposition and time of burial by taking into account the potential effects of bioturbation. Pollen analysis served to reconstruct the vegetation during the various phases.

A first minor phase of aeolian activity already started before approx. 5,000 BC, followed around 4,000 BC by a second phase and a rather massive third phase around 3,000 BC. After a long phase of soil formation, the latest, massive drift sand phase started around the $14^{\text {th }}$ to $15^{\text {th }}$ century. It clearly represents the classic drift sand phase that started in the Late Middle Ages in the Netherlands. Sand drifting followed on soil forming phases during which the vegetation became increasingly dominated by ericaceous plants and culminated in heathlands. The first three aeolian phases and associated heathlands are much older than generally assumed for heathland and drift sand to occur in the Netherlands. Moreover, podzolisation was found to have started very early, true podzols already occurring before 4,000 BC.

Around 3,000 BC groundwater in the area reached a maximum altitude of about $230 \mathrm{~cm}+\mathrm{NAP}$, resulting in local open water in the area. This rise is probably linked to the development of the Dutch coastal area, where at that time peat accumulated and drainage was poor, inducing a rise of the groundwater level in 'het Gooi'. This groundwater level fell later on, to never reach this altitude again. The Groot Wasmeer was formed by local stagnation on a slowly permeable podzol and already reached a level of 320-325 cm +NAP by $400 \mathrm{BC}$, which more or less equals its $20^{\text {th }}$ century level.

The results demonstrate that earlier concepts on the occurrence and age of aeolian phases, podzols and heathland vegetations in the Netherlands are far too schematic, and that early, pre-agricultural cultures may already have had an impact on the stability of fragile cover sand landscapes, e.g. through burning. Results are in line with those from several contemporary studies on early prehistoric cultures and their impact in river dune areas in the Central and Eastern Netherlands.

Keywords: Holocene, OSL dating, Polycyclic drift sands, Podzolisation, Paleohydrology

\section{Introduction}

Large parts of North-West Europe were covered with a blanket of aeolian sands during the Weichselian. For a long time it was assumed that these cover sand landscapes were marked by low dynamics during most of the Holocene, i.e. up to the Late Middle
Ages, when serious soil degradation induced renewed aeolian activity and the genesis of so-called drift sands (e.g. Koster, 2010). Recent work by Tolksdorf \& Kaiser (2012), however, suggests that sand drifting continued until the mid Atlantic $(4,500 \mathrm{BC})$ and started again around 2,000 BC, likely due to intensified land-use in the Late Neolithic. Furthermore, Willemse 
\& Groenewoudt (2012) showed that sand drifting along streams and rivers in the Netherlands may have occurred as early as 3,800 BC, and was widespread from around 2,000 BC. This early onset of sand drifting was attributed to agricultural activity on soils that were impoverished as a result of natural soil depletion.

In this paper, we contribute to the understanding of Holocene landscape evolution in the Dutch cover sand area by exploiting a unique research opportunity offered by a large-scale soil remediation project in the Laarder Wasmeren area near Hilversum, the Netherlands, which started in 2007. This nature reserve with drift sands and several lakes that originally were fens or bogs, is set in a large glacial meltwater valley, cut through ice-pushed ridges and with a thick Late Pleistocene fill, topped by Late Weichselian cover sands and Holocene drift sands (Fig. 1a-c). The project involved the removal of heavily polluted sludge that occurred as a more or less continuous layer in the lakes and on the adjacent land surface, and as infill of an intricate network of ditches and canals (Sevink et al., 2008; Sevink, 2010) (Fig. 2a and b). Upon its removal the underlying soils and sediments were exceptionally well exposed over large areas and to a considerable depth (up to 3 metres), allowing for detailed observations on a complex of Late Weichselian and Holocene sandy deposits (Fig. 1d-h).

The Holocene deposits exhibit a very complex stratigraphy and genesis, i.e. four drift sand phases, two aquatic phases (marshy to lacustrine) and five phases of soil formation. Such complex stratigraphy is unique for the Netherlands. Consequently, the area has been studied in detail, including a.o. OSL dating of the various local deposition phases and pollen analysis of a number of sedimentary sequences. Results from this multidisciplinary study are reported in this paper and though pertaining to local phases in a relatively small Dutch region - 'het Gooi' - they provide new data on the origin and age of early drift sands, on the Holocene vegetation history, and on the onset and timing of podzolisation in the Netherlands. Only the generals of this vegetation history are described, a detailed study will be published elsewhere (Doorenbosch, in prep).

\section{General information}

\section{The Laarder Wasmeren area (LWM): geology, hydrology, and history}

During and after ice advance in the Saalian, a NW-SE orientated glacial meltwater valley was incised through the ice-pushed ridges in the southern part of 'het Gooi' and adjacent province Utrecht (see Fig. 1). Fluvio-glacial sands and gravels subsequently filled this valley, with a total thickness of several tens of metres. During the Weichselian, fluvio-periglacial and aeolian sediments further flattened the relief to a few tens of metres (Koopman \& Pfeifer, 2012). In the valley, drift sand dunes and sheets were deposited during the Holocene as a consequence of local reworking of cover sand. The Laarder Wasmeren are situated in this valley at approximately 2-5 m +NAP (Dutch Ordnance Datum), whereas the eroded remains of the original ice-pushed ridges reach heights of 10-27.5 m +NAP (Fig. 1).

The groundwater system in 'het Gooi' has been extensively studied (Schot, 1989 and Velstra et al., 2004). The 'Wasmeren' were Late Holocene fens and bogs that originated through stagnation of water on impervious podzols and were fed by precipitation. Under 'natural conditions' groundwater flowed from the higher ridges towards the meltwater valley. During the last century, from around 1925 onward, the groundwater level was lowered through extraction for drinking water and flow paths were seriously altered and in places even inversed. This extraction was partly compensated by discharge of wastewater from an urban sewage system of Hilversum into the LWM area, creating and feeding lakes where this water infiltrated, leaving behind a highly polluted sludge. Groundwater extraction was reduced, from about 20 million $\mathrm{m}^{3}$ in the seventies to 14 million $\mathrm{m}^{3}$ in 1989 and later on to 7 million $\mathrm{m}^{3}$. Upon the recent sanitation of the LWM area, the discharge of water stopped, leading to partial restoration of the 'natural' groundwater level and groundwater flow. Fens once more became solely fed by precipitation. Several authors (e.g. Schot \& Engelen, 1989; Colaris, 1998; Sevink et al., 2012) described the complex recent history of extraction, infiltration and lateral seepage towards deep polders (e.g. Horstermeer). At present, the seasonally highest groundwater level in the LWM area is at about $1.5 \mathrm{~m}+\mathrm{NAP}$, i.e. distinctly below the natural ground surface.

A detailed review of earlier studies on the vegetation during the Holocene has been given by Colaris (1998), including results from various palynological studies on the impact of prehistoric land use (e.g. Casparie \& Groenman-van Waateringe, 1980). As to the early land use history of 'het Gooi', Wimmers et al. (1993) state that the first evidence of significant agriculture dates back to the Middle Neolithic Funnel Beaker culture (around 3,400-2,900 BC), but the 'landnam' (or slash and burn) during that period had a limited impact on the vegetation, with only local and temporal transformation of forest into herbaceous vegetation with minor occurrence of Calluna vulgaris (see also De Smidt, 1975). In the subsequent Late Neolithic (2,900-2,000 $\mathrm{BC})$, land use became more intensive and cultural remains of its Beaker cultures (e.g. Bell Beaker and Corded Beaker) are widespread, including a fairly large number of burial mounds, such as on the Zuiderheide immediately $\mathrm{N}$ of the LWM area.

Fig. 1. Location of the LWM area and sites. a. Location and altitude of the Laarder Wasmeren area. Ice-pushed ridges are in red; $b$. Details of the area, with its former lakes; c. Location of the major sections (Roman numbers); d. Early paleosol (S1-3) in a former canal; e. Lake bottom of the Groot Wasmeer with bleached sands; $f$. Complex surface of the former Vuilwaterplas after its sanitation; $g$. Surface of the Langewater with two parallel canals, exhibiting a single podzol; $h$. NE of the Groot Wasmeer with abundant cart tracks. 

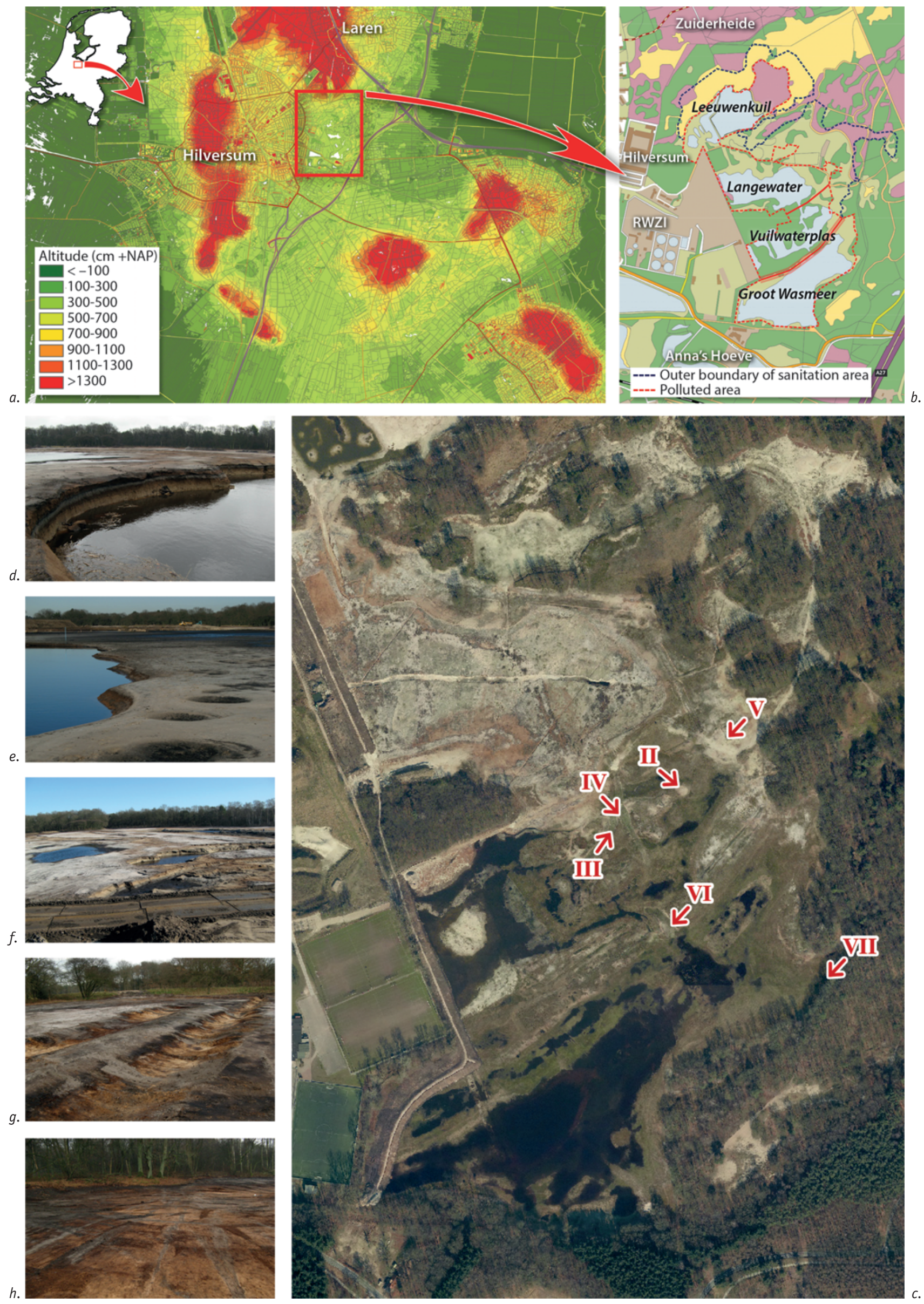
According to Wimmers et al. (1993), it was during the Bronze Age (2,000-800 BC) that the earlier, Neolithic 0ak-Lime forest was gradually transformed into 0ak-Birch forest and heathland dominated by Ericales became more prominent. It should be emphasised that the attribution to man-induced degradation of the general change of the forest vegetation towards Ericales dominated heathland is challenged by Van Geel \& Bos (2007). They found that heath vegetation already occurred during the Early Atlantic on Pleistocene sands to the west of 'het Gooi' (Nederhorst den Berg), which gradually became covered by peat as a result of sea level rise during the Atlantic. However, it is not clear whether this was a local phenomenon, linked to the deteriorating drainage of the area concerned (i.e. a wet heath), or a more regional phenomenon. The chronology for the various archaeological cultures is after Louwe Kooijmans et al. (2005).

\section{Drift sands}

Extensive reviews on the origin and development of inland drift sands in the Netherlands are by Koster (2005b), Riksen et al. (2006) and Koster (2009), while recently Fanta \& Siepel (2010) published a multi-authored book on 'Inland drift sand landscapes' that contains several contributions on the topic. Studies on the drift sands of the LWM area and in fact the whole 'het Gooi' do not exist, but it is generally assumed that the genesis and characteristics of these sands conform to the overall trend in the Netherlands (e.g. Koopman et al., 2010). Relevant information from the above reviews is summarised below. For the terminology used we refer to Koster (1982), while the lithostratigraphic subdivision of the cover sand is according to van der Hammen et al. (1967).

In the Netherlands, inland drift sand areas formed largely as a result of anthropogenic degradation of podzols, developed in Pleistocene cover sands. Minor source areas were river dunes along the Rhine-Meuse system and smaller rivers in the east of the Netherlands (e.g. Overijsselse Vecht and Dinkel). The bulk of the drift sands is assumed to result from serious agricultural overexploitation, which started during the early Late Middle Ages (e.g. Castel et al., 1989; Spek, 2004; Heidinga, 2010; Koster, 2010), when agriculture massively expanded in hitherto 'waste lands' with fragile sandy soils. Drift sands reached their zenith by the late $19^{\text {th }}$ century, when land pressure was such that farmers were forced to exploit heathlands to the maximum. At that time, active drift sand covered about $950 \mathrm{~km}^{2}$ (Koster, 2010). The degradation virtually stopped when fertilizers became available at a large scale and the 'waste lands' were reclaimed for agriculture or were afforested with Scots Pine. Nowadays, active inland drift sand is scarce and disappearing as a result of ongoing vegetation succession (e.g. Fanta \& Siepel, 2010; Sparrius, 2011). Drift sands thus were typically linked to agricultural overexploitation, though some researchers stress the role of wind erosion during periods of adverse climatic conditions, including the Little Ice Age (see e.g. Heidinga, 1984 and 2010; Jungerius \& Riksen, 2010). However, the latter attribution remains rather hypothetical, not being based on systematic dating of drift sand deposits and their phasing.

Until fairly recently dating drift sands and their phases was notoriously problematic in case that archaeological materials were absent as well as organic material that allowed for reliable and precise ${ }^{14} \mathrm{C}$ dating such as peat layers and charcoal. This holds for most drift sands, as has been extensively described by Castel (1991), Koster et al. (1993), and Van Mourik et al. (1988 and 1995). AMS ${ }^{14} \mathrm{C}$ dating solved some of these problems, allowing for dating of specific plant remains. However, such remains (e.g. seeds) are largely limited to peat layers and intercalated peat layers are truly rare in the predominantly dry drift sands, thus hampering improved radiocarbon dating of phases. Early attempts to date aeolian deposits by thermoluminescence (Dijkmans et al., 1988 and 1992; Dijkmans \& Wintle, 1991) were fraught with uncertainties and apparently resulted in an underestimation of ages by $20-40 \%$, when compared with existing radiocarbon chronology. Moreover, these early attempts largely concerned the dating of cover sands (Koster 2005a; Wallinga et al., 2007). Recent relevant OSL studies concern coastal dune sites in the Netherlands and adjacent countries (Radtke, 1998; Strickertsson \& Murray, 1999; Murray \& Clemmensen, 2001; Ballarini et al., 2003; Bateman \& Godby, 2004; Madsen et.al., 2007; Cunningham et al., 2011), and a few inland dune sites (Hilgers et al., 2001; Schilder et al., 2006; Hilgers, 2007; Van Mourik et al., 2010; Derese et al., 2010; Tolksdorf \& Kaiser, 2012; Willemse \& Groenewoudt 2012).

OSL results for the inland dunes confirmed that most ${ }^{14} \mathrm{C}$ datings of soil organic matter from drift sand are indeed unreliable and shed doubt on the earlier published ages of drift sands and drift sand phases. Moreover, the OSL datings show that in the Netherlands and Germany, in addition to the 'classic' medieval and later drift sands, older drift sands occur that even date back to prehistoric times. Van Beek (2009) and Willemse \& Groenewoudt (2012), for example, documented anthropogenic drift sands from the Netherlands that date from the Neolithic to Late Iron Age and are fairly common in river dune areas in the east of the Netherlands. In their regional study, Tolksdorf \& Kaiser (2012) convincingly demonstrated that aeolian activity continued after the end of the Early Dryas up to the Mid-Atlantic (cf. 4,500 BC) throughout North-West Europe, though at a more local scale than the well-known medieval and post-medieval drift sands. From the Late Neolithic onward, aeolian sedimentation repeatedly occurred and was linked to periods of increased human impact. Similar results were found in England (Bateman \& Godby, 2004). In conclusion, there is an increasing recent body of evidence for early drift sands in the Netherlands, though predominantly from river dune areas where sources of 'fresh sand' were nearby.

While drift sands are typically composed of well-sorted quartzitic sands, they exhibit a range in facies types and 
associated structures. Thus, Koster (1988, 2005b), following studies by Schwan $(1986,1988)$ and Ruegg $(1983)$, distinguished a series of facies types on the basis of primary sedimentary structures, indicative of tractional or grainfall deposition. In summary, these included: a) structures representing completely dry aeolian transport and accumulation; b) structures reflecting moist to wet aeolian sedimentary conditions; and c) structures indicating aeolian-lacustrine conditions to conditions of low or high energy running water in aeolian settings. The structures involved vary from a) evenly laminated, (sub)horizontal lamination or slightly undulated lamination, dune-foreset cross-bedding, granule ripples and deflation horizons, to b) 'layer-cake' alternating sand and silt layers, wavy and crinkly laminae, adhesion lamination and small-scale low-angle crosslamination, and to c) ripple cross-lamination, scour and fill structures and large-scale trough cross-bedding.

Drift sands (and cover sands) also display a wide range of (secondary) syn- and post-depositional deformation structures (Pye \& Tsoar, 1990). Amongst these load structures are particularly relevant, since these were widely encountered in the drift sands of the LWM-area. Load structures (Reineck \& Singh, 1980) are commonly found in shallow-water environments, where wet surficial conditions are occasionally interrupted by sand deposition. Naturally, these conditions preferentially occur on relatively flat aeolian surfaces and interdune areas under the effect of temporary heavy rainfall or a high groundwater level. More or less similar features may develop by the filling of scour marks by flowing water.

\section{Methods}

\section{Field methods}

For the area as a whole, a detailed GPS-based topographic survey with several thousand points ( $\mathrm{x}, \mathrm{y}$ and $\mathrm{z}$ coordinates) was available, through which topographic features were recorded. Numerous observations in ditches, trenches, and other exposures provided a detailed insight into the geological structure of the area and allowed for the selection of representative profiles in which the complex history was well recorded. Profiles were described using the FAO guidelines for soil profile description and sampled for further studies. X/Y/Z coordinates were based on the detailed topographic survey and checked by additional GPS measurements. Lateral relations between layers and horizons observed in these profiles were established through observations in existing ditches and trenches, or by hand digging additional pits/profiles.

In the field, Holocene drift sand may be hard to distinguish from Pleistocene cover sand when the top of the cover sand does not show the characteristic strongly developed Holocene podzol, because of strong deflation prior to deposition of drift sand (see e.g. Koster 1982). A further complication may be that in drift sand podzolisation may proceed very rapidly and thus the presence of a podzol alone cannot be used as decisive argument for the age - Holocene or Pleistocene - of the sand in which it formed (e.g. Sevink et al., 1970; Koster, 1982; Van Mourik et al., 1995). It should be emphasised that such problematic field identification is largely restricted to profiles observed in isolated pits and small exposures. In large sections, such as encountered in the LWM area, stratigraphic relations are far less problematic and can generally be established unambiguously (see also Koster, 1982).

Samples were taken for soil chemical analyses to characterise the podzolic paleosols, for radiocarbon dating (incidental), and for grain-size analyses. From all major profiles, large monoliths were taken for additional studies, particularly the identification of pollen and other palynomorphs, and smaller monoliths in opaque PVC tubes for OSL dating. Lastly, large plastic peel monoliths were made of all profiles for description of sedimentologial features and facies types following Koster (1988, 2005b).

\section{Laboratory methods}

Soil chemical analyses aimed at characterising (the extent of podzolisation in) the main paleosols. $\mathrm{EC}_{25}$ was estimated in a demineralised $\mathrm{H}_{2} \mathrm{O}$ extract (w/v: $1: 2.5$ ) in which subsequently soil $\mathrm{pH}$ was measured with a glass electrode. Soil $\mathrm{pH}$ was also measured in a $0.01 \mathrm{M} \mathrm{CaCl}_{2}$ soil solution (w/v: $1: 2.5$ ). Total carbon $(\mathrm{C})$ and nitrogen $(\mathrm{N})$ were measured with a VarioEL (Elementar) CNS auto-analyser. $\mathrm{C}$ equals organic carbon, since carbonates were absent. LOI $_{375}$ was estimated by heating oven-dry soil to $375^{\circ} \mathrm{C}$ for 16 hours. Sodium pyrophosphate extractable $\mathrm{Al}$, Fe and $\mathrm{Si}\left(\mathrm{Al}_{\mathrm{p}}, \mathrm{Fe}_{\mathrm{p}}\right.$ and $\left.\mathrm{Si}_{\mathrm{p}}\right)$ were determined in field-moist samples (fine earth fraction), while dithionite-citrate extractable $\mathrm{Fe}$ and $\mathrm{Al}\left(\mathrm{Fe}_{\mathrm{d}}, \mathrm{Al}_{\mathrm{d}}\right)$ were determined in ground and dried samples (Van Reeuwijk, 2002).

According to Van Reeuwijk (2002) sodium pyrophosphate extracts $\mathrm{Fe}$ and $\mathrm{Al}$ that is associated with organic matter from soils. It dissolves amorphous inorganic oxides only slightly and silicate minerals and crystalline $\mathrm{Fe}$ and $\mathrm{Al}$ oxides are not attacked to a significant extent, while dithionite/citrate extracts both crystalline and non-crystalline compounds. Ratios of $\mathrm{Fe}_{\mathrm{p}} / \mathrm{Fe}_{\mathrm{d}}$ etc. thus provide an indication for the extent to which $\mathrm{Fe}$ and $\mathrm{Al}$ occur in complexed form in the soil and of their illuvial accumulation.

Grain-size distributions were established, after pretreatment of samples by $\mathrm{H}_{2} \mathrm{O}_{2}$ and $\mathrm{HCl}$, and wet sieving over a $63 \mu \mathrm{m}$ sieve, by dry sieving the fraction $>63 \mu \mathrm{m}$ ( 5 subfractions), and by sedimentation and pipetting of the fraction $<63 \mu \mathrm{m}$. Because of the very low content of the latter fraction only two subfractions were separated ( $<2 \mu \mathrm{m}$ and 2-63 $\mu \mathrm{m})$. Sedimentary facies determination is based on field properties (e.g. structure, texture, local relief), grain-size analyses, and observations on plastic peel monoliths made from all relevant profiles. Description of sedimentologial features and facies types follow Koster (1988, 
Table 1. Grain-size distributions of cover sands (LWM III and V: 100-105 $\mathrm{cm}$ ) and drift sands (LWM III 30-35 cm and LWM V 25-30 cm). Geometric parameter values according to the method of Folk \& Ward (1957).

\begin{tabular}{lllll}
\hline Profile & LWM III & \multicolumn{3}{l}{ LWM V } \\
\hline Depth & $30-35$ & $100-105$ & $25-30$ & $100-105$ \\
Median $(\mathrm{D} 50-\mu \mathrm{m})$ & 179.8 & 176.4 & 167.9 & 172.1 \\
Mean $(\mathrm{x}-\mu \mathrm{m})$ & 180.7 & 176.9 & 168.1 & 173.4 \\
Sorting ( ) & 1.623 & 1.456 & 1.452 & 1.578 \\
Skewness (Sk) & -0.004 & 0.021 & 0.033 & 0.015 \\
Kurtosis (K) & 1.091 & 1.089 & 1.166 & 1.109 \\
\hline
\end{tabular}

2005b, see Table 2) and standard statistical grain-size parameters are according to Folk and Ward (1957).

For pollen analysis, sub-samples of ca $1 \mathrm{cc}$ were treated with $\mathrm{KOH}$ and subsequently acetolysed according to Faegri \& Iversen (1989). For the separation of organic material from mineral particles, a bromoform-ethanol mixture (specific gravity 2) was used. The microfossils were embedded in glycerine jelly and microscope slides were sealed with paraffin. Pollen was identified using Beug (2004), Moore et al. (1991) and a pollen reference collection.

In podzols, the complex interaction over time between acidification/podzolisation and bioturbation results in a characteristic distribution of pollen with depth (Dimbleby, 1985). Taxa dominating the lower soil horizons indicate vegetation types that previously occupied the land, while those in the original topsoil reflect the vegetation immediately prior to the burial of the soil, such as by younger drift sand. This pattern

Table 2. Sedimentary structure of section LWM III. For the units distinguished, see Fig. 7.

\section{Unit Description}

1 More or less structureless sand with abundant root structures, the lower $5-7 \mathrm{~cm}$ of this unit shows distinct deformation by scour and fill structures and convolute bedding

2 Distinct, even parallel horizontal lamination, only the lowermost few centimetres shows small-scale, low-angle cross-lamination

3 Partly structureless, partly strongly deformed lamination due to scour and fill structures and convolute bedding, erosive lower boundary

$4 \quad$ Fine-grained sand layer with relatively high organic matter content, strongly deformed by (secondary) load casting

5 Cover sand with indistinct structures due to soil formation

6 Wavy parallel lamination with fine scour and fill structures, especially at the top, and occasionally small-scale cross-lamination

$7 \quad$ Strongly deformed wavy parallel lamination with scour and fill structures and small-scale cross-lamination, possibly small-scale frost cracks and fine adhesion structures may be complicated by the eventual presence of older pollen that was deposited at the sampling site together with the accumulating sand, such as in case that the aeolian material is reworked from older pollen bearing strata or soils (e.g. Van Mourik, 2003, Van Mourik et al., 2011). In summary, most indicative for the contemporary site conditions is pollen in the (former) topsoils, e.g. Ah horizons, while in lower soil horizons with low pollen content the origin and age of the pollen assemblage is rather uncertain.

AMS radiocarbon dating was carried out at the Centre for Isotope Research of Groningen University. The result is reported in conventional Radiocarbon years, which includes correction for isotopic fractionation using the stable isotope ratio $\partial^{13} \mathrm{C}$, and usage of the conventional half-life (Mook \& Van der Plicht, 1999). For calibration into calendar age the recommended calibration curve intcal09 (Reimer et al., 2009) was used. The ${ }^{14} \mathrm{C}$ date is reported in y cal BC (Table 3 ).

\section{OSL dating}

Optically Stimulated Luminescence dating (OSL) was used to determine the time of deposition and burial of the deposits. Analysis was performed at the Netherlands Centre of Luminescence dating (NCL) of the Delft University of Technology. For a general description of the OSL dating method, we refer to Wintle (2008). The OSL samples were collected in opaque PVC tubes. Material from the outer ends was light-exposed during sampling and was used for dose rate estimation, whereas luminescence measurements were performed on material from inside the tubes.

For the dose rate calculation methods, we refer to Wallinga and Bos (2010). To account for the effect of soil moisture on the dose rate, we used the measured water content (\% weight of water / weight of dried sediment) with a minimum of $10 \%$ for lacustrine samples and 5\% for aeolian samples. In all cases a relative uncertainty of $25 \%$ was attributed to account for moisture content variations in the past. Contributions of cosmic rays to the dose rate were included based on Prescott and Hutton (1994). Depending on the local stratigraphy we assumed immediate burial to present depth or gradual burial.

Equivalent-dose measurements were performed on quartz grains of 180-212 $\mu \mathrm{m}$, mounted on 3-mm aliquots. The SingleAliquot Regenerative dose procedure (Murray \& Wintle, 2003) was used for equivalent dose estimation. Based on preheatplateau tests, we selected a preheat of $220^{\circ} \mathrm{C}$ for $10 \mathrm{~s}$; for the three youngest samples a $200^{\circ} \mathrm{C}$ preheat was used to avoid thermal transfer effects. In all cases heating after the testdose (cutheat, $0 \mathrm{~s}$ ) was to the same temperature as for the preheat. To maximise the contribution of the fast OSL component to the signal, early background subtraction was used (Ballarini et al., 2007; Cunningham \& Wallinga, 2010). The net OSL signal used for analysis comprised of the OSL signal measured during the first $0.8 \mathrm{~s}$ of stimulation, minus the signal during the subsequent 
$0.8 \mathrm{~s}$. After each SAR cycle, a $40 \mathrm{~s}$ high-temperature bleach with blue diodes is performed at $20^{\circ} \mathrm{C}$ above the preheat temperature to avoid build-up of charge in traps that are not light sensitive. Single-aliquot equivalent-dose estimations were accepted if recycling was within 10\% from unity, response to a zero dose was $<10 \%$ of the first regenerative dose, and infrared response or infrared depletion were low (IRSL $<20 \%$ of OSL, or depletion of OSL due to IR bleach $<10 \%$; see Duller, 2003). The adopted procedure was checked through a dose recovery experiment, which yielded an acceptable dose recovery ratio of $0.95 \pm 0.01(n=71$, overdispersion $9.2 \%$ ).

Burial dose estimates were obtained from the equivalent dose estimations using the Central Age Model (CAM; Galbraith et al., 1999). The CAM model also indicates how much spread in the equivalent dose distribution cannot be explained from measurement uncertainties; this is referred to as overdispersion. To avoid bias due to extreme outliers, any equivalent dose estimates deviating more than three standard deviations from the sample mean were removed prior to further analysis.

Three young samples (LWM VI-15 and -16, LWM VII-18) showed high overdispersion ( $>35 \%$ ) and skewed equivalent dose distributions. This scatter is attributed to incomplete resetting of the OSL signal in part of the grains, and we employed the Minimum Age Model (MAM; Galbraith et al., 1999) to determine the age. The MAM was run in a bootstrapped fashion to improve uncertainty estimates (Cunningham \& Wallinga, 2012). The MAM requires an estimate of the overdispersion for well-bleached samples; this estimate was obtained from the distribution of overdispersion values determined for each of the samples. By running the MAM on this dataset (with expected overdispersion in this dataset zero), we obtained an estimate of $14.9 \pm 0.4 \%$. This value, with uncertainty, was used as input for the bootstrapped MAM analysis of the equivalent-dose distributions for the three young samples.
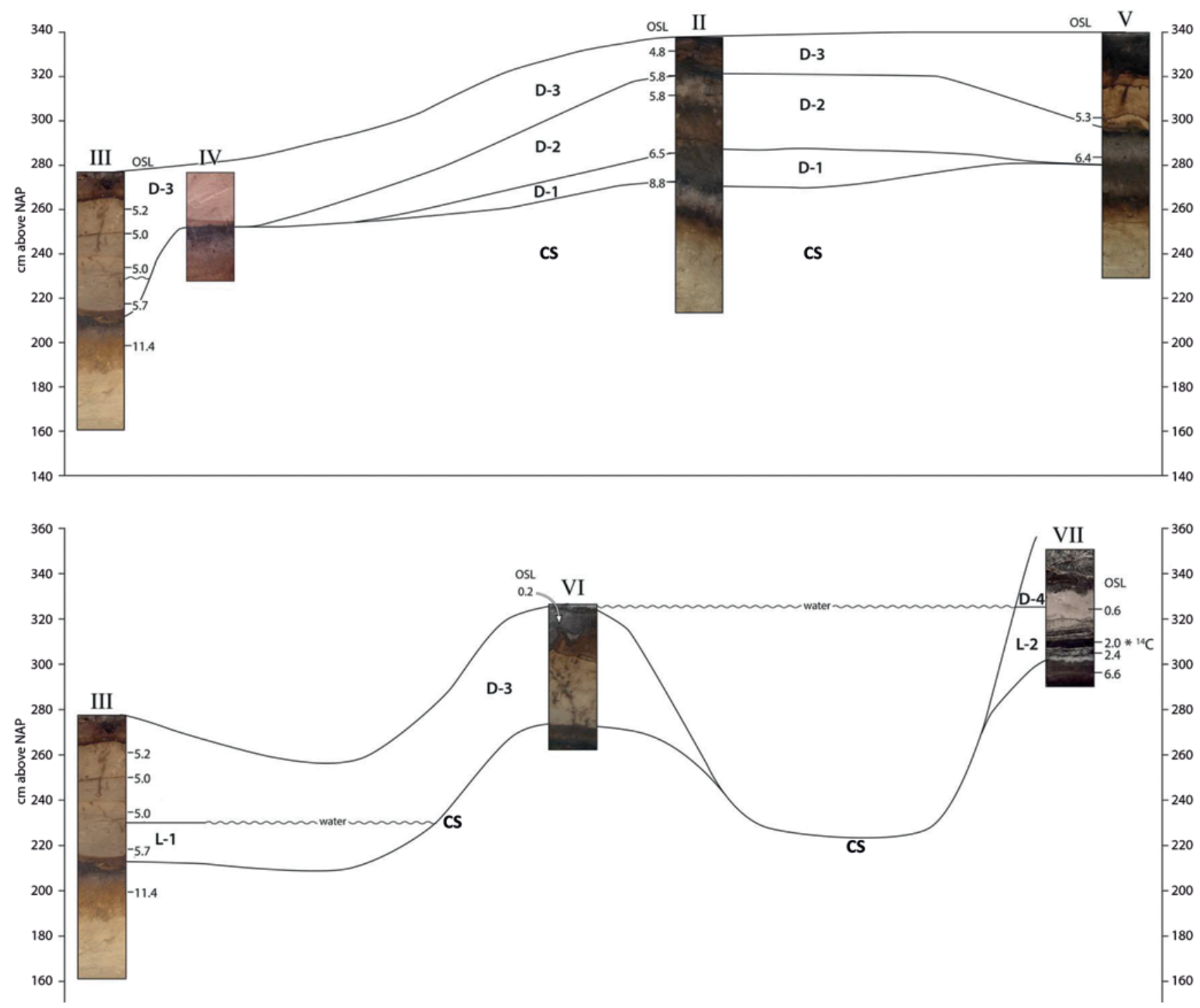

Fig. 2. Cross-sections with profiles, drift sand phases and datings (OSL in ka and ${ }^{14} \mathrm{C}$ in ky cal BP). For symbols used, see text. Section A =LWM III/IV/II/V; Section B = LWM III/VI/VII (for locations see Fig. 1). Maximum level of open water during phases L-1 and L-2 is indicated with $m$ water $m$. For soil phases, see individual profiles and Fig. 13. 
OSL ages were calculated by dividing the sample burial dose by the dose rate and are expressed in ka relative to the year of sampling, which was 2008 (Table 3). Quoted uncertainties contain random and systematic errors in both the dose rate and burial dose assessment, and reflect the 1-sigma confidence interval.

\section{Results}

\section{General observations}

In Fig. 1 an overview of the area is shown, while cross-sections with profiles that were studied in detail are given in Fig. $2 \mathrm{a}$ and $2 b$.

In the field, cover sand - most probably Younger Cover Sand II, deposited during the Younger Dryas - could be easily distinguished from drift sand, the boundary being marked by the presence of an earliest paleosol, which considering its habitus - distinct podzolisation - must be of Holocene age and could be traced over large areas. The various profiles presented in Fig. $2 \mathrm{a}$ and $2 \mathrm{~b}$ exemplify this. As to the area as a whole, deflation seemed to have been of minor importance and drift sands accumulated in particular in the NE, partly in the form of a more or less continuous sheet and some more isolated dunes. Evidently, the absence of a clear erosional hiatus at the base of the drift sand(s) enhanced the identification of the stratigraphic boundary between the Pleistocene and Holocene aeolian sands. At the same time, this absence evidenced that the source areas of drift sand most probably were situated to the southwest, outside the LWM area.
Distinction could be made between a) the central area with a complex stratigraphy (the Vuilwaterplas area), b) the Groot Wasmeer and particularly its southeastern border area with complex deposits, and c) the northern and eastern areas with a simpler stratigraphy (the Langewater area). General characteristics of the three sub-areas are described first, followed by the profiles studied in more detail. Phases in soil formation and sedimentation, indicated in the sections (see e.g. Fig. 2a and b) were distinguished in the field. They are indicated with the character $\mathrm{D}$ and a numerical suffix in the case of drift sand phases, or the letter L with similar suffix for 'lacustrine' phases (i.e. phases of temporarily or permanently open water due to a high groundwater level or to stagnation on an impervious layer). A 'lacustrine phase' is evidenced by the occurrence of such phenomena as load casting, strongly bleached sand as encountered in fens and similar acid lakes (see e.g. Fig. 1e), or peat layers. Phases of soil formation are indicated with the character $S$ and a suffix. 'Recent drift sand' was identified as such by the very limited development of its soil, which consisted of a litter layer over an Ah or AEh horizon, and lacked an E or B horizon.

\section{Central area}

Complex drift sand profiles were particularly encountered in the Vuilwaterplas and its NE-border zone, with a rather prominent aeolian relief. The Pleistocene cover sand had an undulating surface, with a shallow large depression of which the lowest part was at around $215 \mathrm{~cm}+\mathrm{NAP}$ near LWM III (see Fig. 1d and Fig. 2b). Over most of the area, drift sands covered

Table 3. OSL ages and ${ }^{14} \mathrm{C}$ age. OSL ages are in ka relative to year of sampling (2008).

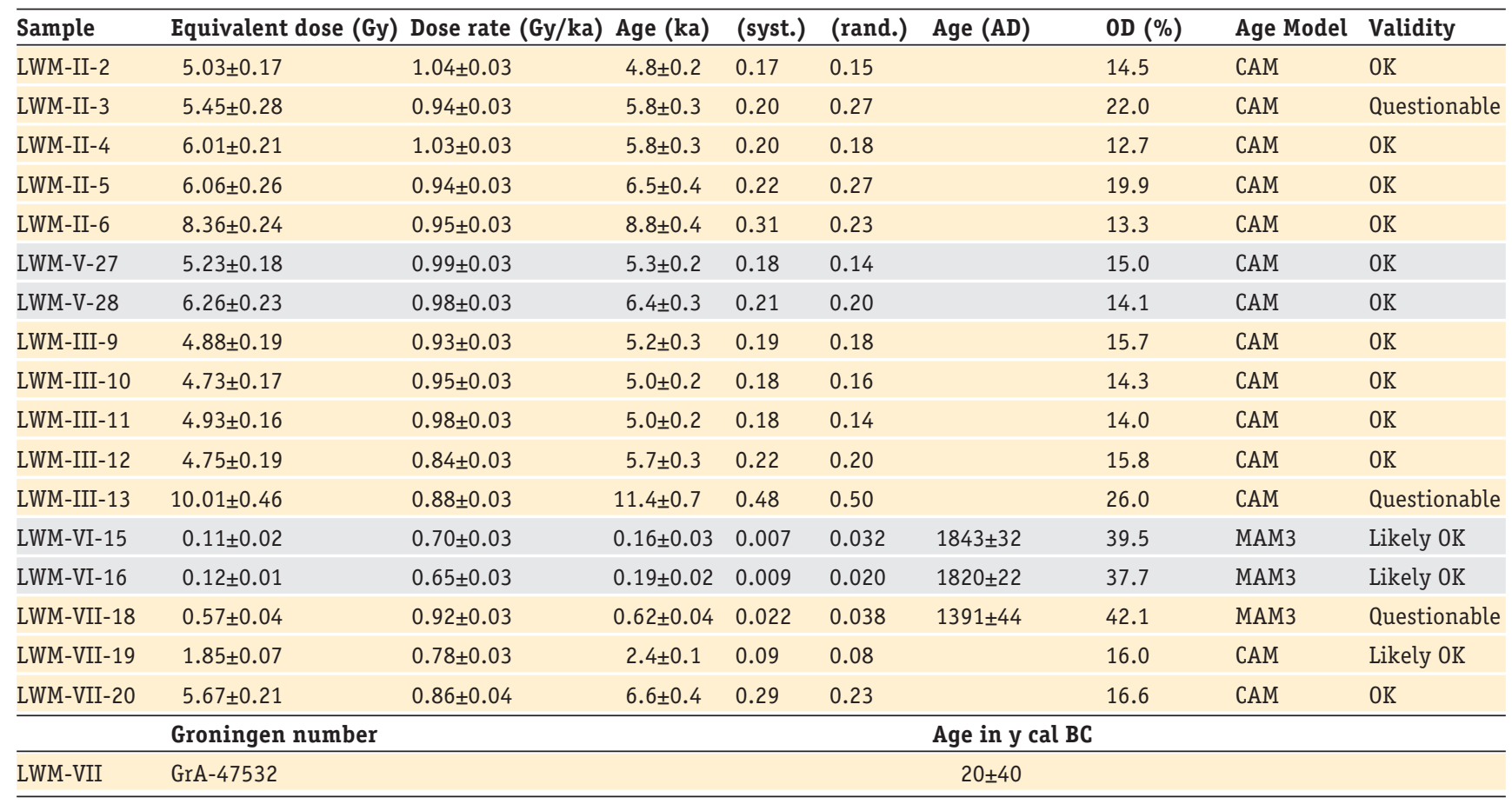


this surface. The modern land surface exhibited a prominent podzol, in places with abundant cart tracks (see Fig. 1h). Recent drift sand was absent.

The most complex profiles occurred in between LWM IV and $\mathrm{V}$ to the NE of the depression. Three drift sand layers were found on top of the cover sand, with four soil phases (see e.g. LWM II). The first two drift sand phases (D-1 and -2) were of limited dimensions, while the third (D-3) was widespread and covered most of the central area. In the latter drift sand, a prominent and highly characteristic podzol with a thick stagnative spodic B had formed (S-4). Further NE, the soil phases S-1, S-2 and, eventually, S-3 graded into one single phase, represented by a distinct and thick Ah/E/Bh sequence in cover sand (see e.g. Fig. 2b).

In the large depression, the soil phases $S-1, S-2$, and $S-3$ could not be separated, and graded into a single soil in cover sand. Based on the observed lateral relations (see e.g. Fig. 2a), the drift sand covering the soil dates from phase $D-3$, but in its lower part evidently had been deposited in an aquatic environment (phase L-1, see Fig. 7). The buried soil could be traced over large distances (see e.g. Fig. 1d and Fig. 11) and was a hydromorphic incipient podzol with weakly developed $\mathrm{E}$ and Bhs horizons (e.g. LWM IV). In the lowest parts of the depression, the surface layers of this podzol had been strongly disturbed by later load coasting (see Fig. 13) in most probably shallow open water (see LWM III), but originally these surface layers were highly organic (more or less peaty). Lateral, at slightly higher altitude, i.e. about $250 \mathrm{~cm}+\mathrm{NAP}$, the soil lacked the prominent load casting features as well as the peaty surface layer (e.g. LWM IV), but its pedogenic features were rather invariable (incipient hydromorphic podzol).

Both to the south and the north, the sequence was less complex, being generally composed of a well-developed podzol in cover sand (presumably Younger Cover Sand II) that represented the combined S-1, S-2 and S-3 soil phases, covered by drift sand (D-3) with the prominent podzol of S-4. This sequence was very prominent in the NE-SW running ridge between the former Vuilwaterplas and the Groot Wasmeer, which showed abundant cart tracks, as well as to the $\mathrm{N}$ of the Vuilwaterplas (see e.g. Fig. 1h).

\section{The Groot Wasmeer and its southern border}

In the central part of the Groot Wasmeer, a single soil occurred with a thick (more than $50 \mathrm{~cm}$ ) very compact brown hydromorphic spodic B horizon overlain by a layer of bleached, white sand (reworked albic material, see Fig. 1e) with abundant load casting features, well visible in both horizontal and vertical sections, particularly in the northeastern border zone. Along its southeastern border, the stagnative podzol was very well preserved, with a thick albic horizon and highly stagnative spodic B horizon. A complex of well-stratified bleached, white sands with common thin peaty intercalations covered the podzol (see Figs $3 b, 5 a$ and 11). This peat at least partially consisted of well-identifiable plant remains, allowing for radiocarbon dating by AMS (see datings, Table 3). Remarkable was the pronounced load casting in the upper part of the albic $E$ and overlying white sandy complex, which in combination with the occurrence of peaty layers testified to the lacustrine origin of these sands (phase L-2). Examples of this load casting are given in Fig. 3b. The lake formed by stagnation on the dense spodic B horizon. Upward, the stratified bleached sand graded into yellowish drift sand (phase D-4) that extended in the form of large dunes to the south and east. These dunes are known to have been active drift sand till the early twentieth century.

Fig. 3. Former southern border of the Groot Wasmeer: a. podzol (CS), covered by stratified bleached sands and peat (L-2), with on top yellowish recent drift sand $(D-4) ; b$. detail with load casting phenomena.

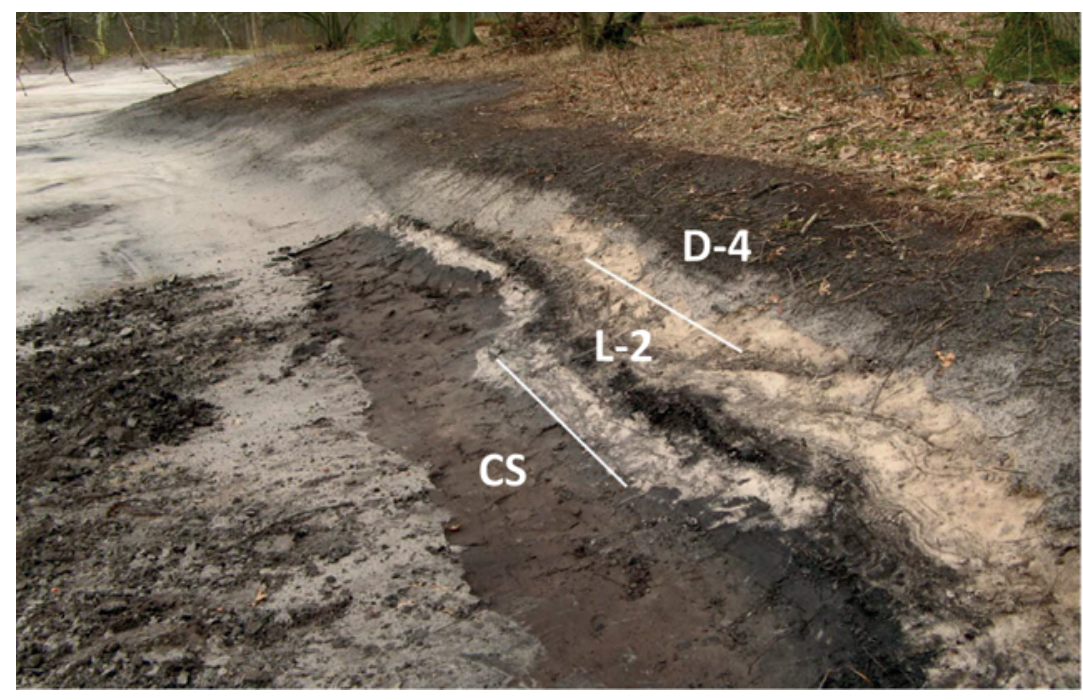

a.

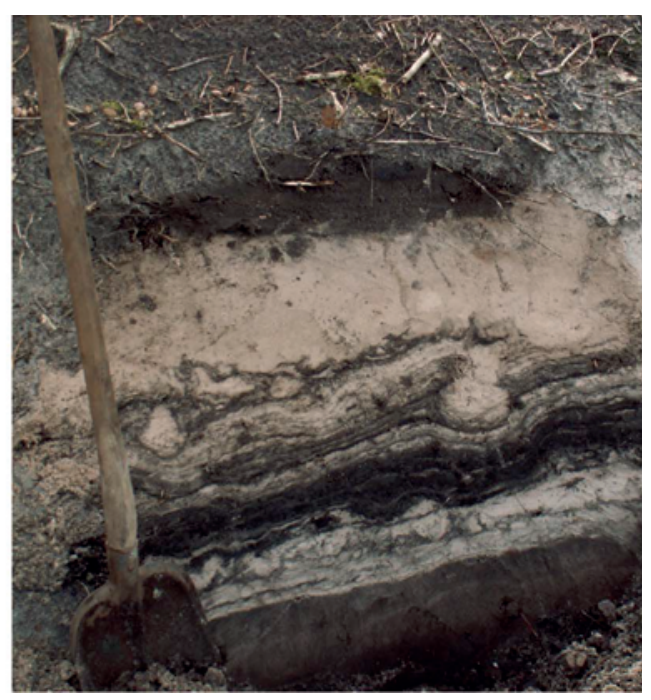

b. 
The highest altitude reached by the white sands complex with prominent load coasting was about 320 to $325 \mathrm{~cm}+\mathrm{NAP}$, an altitude which could be traced all along the border of the Groot Wasmeer and is just about $10-20 \mathrm{~cm}$ below the original top of the ridge that separated the Groot Wasmeer from the Vuilwaterplas (see Fig. 1b). The white sands clearly mark the highest lake level at the time of their deposition and were only observed in the Groot Wasmeer area. In the $\mathrm{N}$ and $\mathrm{E}$, cart tracks ran through the top of the bleached sands complex and in places exhibited clear contemporary load casting, testifying that these carts had been driven through shallow water (see Fig. 1h).

\section{The north and east}

In this part of the area, the aeolian relief was less pronounced and the stratigraphy less complex. Incidentally, towards the NE double podzols were observed: a more recent podzol occurring in a thin sheet of drift sand over an older equally well-developed podzol. Recent drift sand, i.e. at most a few centuries old and still active in the past century, was much more common than in the southern and central areas. Interestingly, it was in this area that an older presumably Late Weichselian (i.e. the Usselo layer) or Early Holocene paleosol, covered by drift sand, was fairly common (Sevink, 2007). It consisted of a truly incipient podzol, which in the upper horizons (dark Ah and bleached E horizons) characteristically holds charcoal fragments (see Fig. 4). They incidentally were up to $1 \mathrm{~cm}$ large and, where identifiable, were from pine trees. In some places, later frost cracks occurred in this layer, testifying to its Weichselian age, but in other places its age was less straightforward. The nature and age of these older paleosols will be discussed in another paper (Sevink et al., in prep).

\section{Distinction between cover sand and drift sand}

The field distinction between cover sand and drift sand was confirmed by the OSL and pollen data (see further on), though in some cases superficial aeolian reworking of the upper horizons (Ah and E) of the podzol in the top of the cover sand could be observed (e.g. profile Groot Wasmeer, Fig. 9). In the field, systematic differences in grain size between cover sand and drift sand were not observed. Grain-size distribution of several drift and cover sand samples (see Table 1) were compared to check potential differences.

The drift and cover sands show remarkably small differences in grain-size distribution. The grain-size fraction 150-210 $\mu \mathrm{m}$ is by far dominant and reaches weight percentages of $33-42 \%$. The fraction $<53 \mu \mathrm{m}$, including organic material, is less than $2 \%$, whereas grains larger than 2,000 $\mu \mathrm{m}$ are negligible. Median and mean values are almost identical as can be expected in strongly unimodal sands. Likewise, sorting values do not show large differences. Skewness values fluctuate around 0.0, indicative of symmetrical grain-size distributions. Finally, kurtosis values, representing the measure of sorting of the central part of the size distribution versus the measure of sorting of the 'tails' of the distribution, are hardly more than 1.0, showing that sorting of both parts of the distribution is almost the same.

These characteristics are in conformity with the usual grain size of Younger Cover Sand and related drift sand deposits (Koster, 1982, 2010; Pye \& Tsoar, 1990). Moreover, it can be concluded that the drift sands represent local re-sedimentation of the underlying cover sands over short distances. Consequently, in this case no distinction can be made between cover sands and drift sands on the basis of grain size alone.

Fig. 4. Drift sand

(D) over podzol

$(P)$ in cover sand

(CS), over Usselo

layer (US), NE of

the Langewater

(see Fig. 1b).

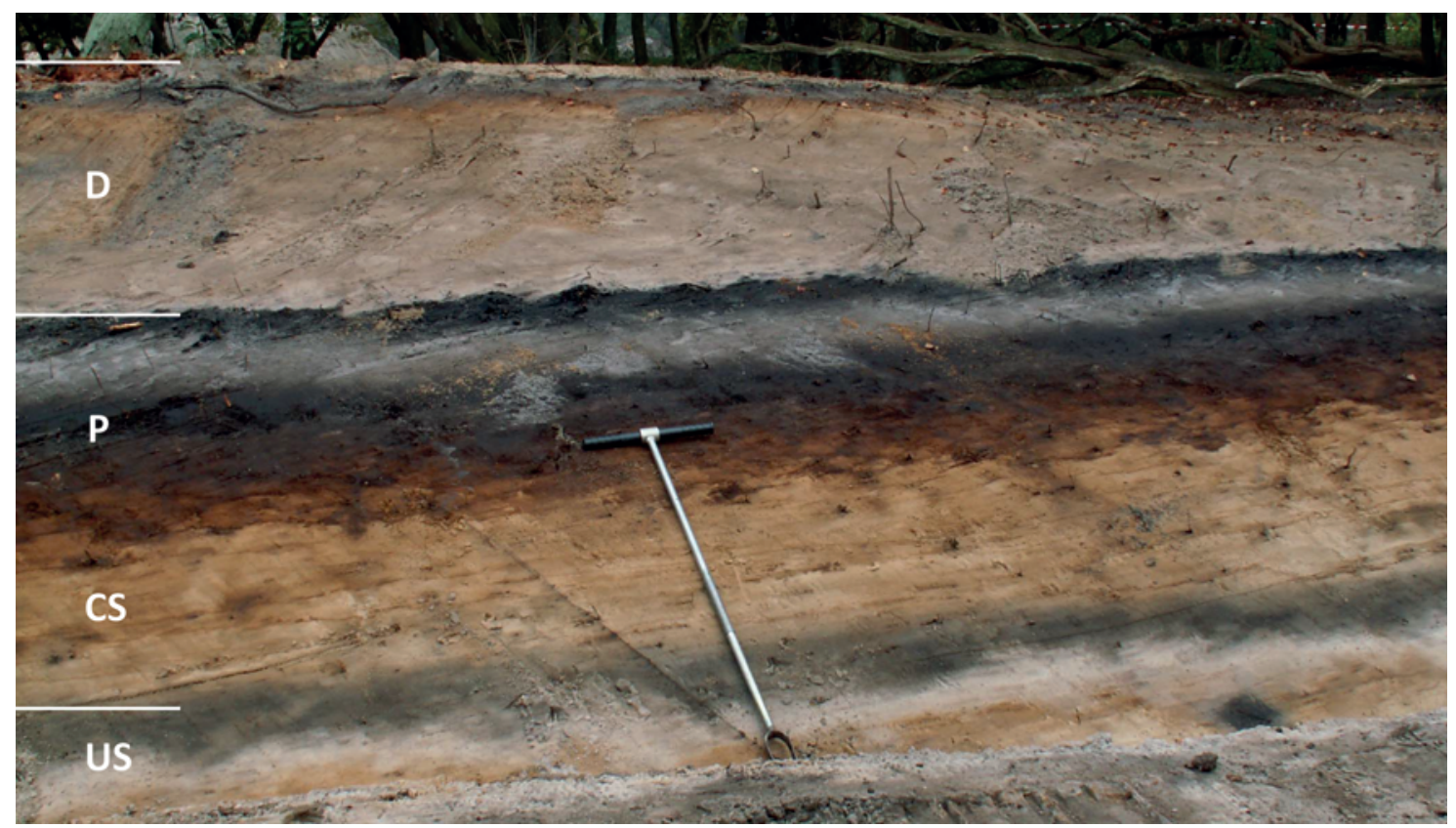




\section{Profiles studied}

\section{The central area (Fig. 3a)}

LWM II is the most complex profile with 4 soil phases and 3 drift sand phases (see Fig. 5). The pollen analysis shows that over time considerable variation occurred in the composition of the vegetation. The overall picture for phase $S-1$ is one of rather open moist/wet heathland vegetation, following on an early Pinus and Corylus dominated wet phase, which probably dates back to the Boreal considering the pollen spectra (Van Geel et al., 1981). It is during this phase S-1 that an incipient hydromorphic podzol was formed. Later soil and drift sand phases all show a large component of Ericales and Poaceae indicative for the presence of heathland, in combination with Alnus and declining Corylus. Overall, from S-2 to S-4/D1-D3, Ericales increase, while the erstwhile dominant Corylus gradually decreases to very low values in S-4/D-3. Alnus, first appearing in significant quantities in S-2/D-1, remains more or less stable at about $20 \%$. Phase S-3 is marked by clear podzolisation, which however does not reach the intensity of phase 4 .

LWM V (Fig. 6) is less complex than LWM II. The soil in cover sand is well represented but probably includes two phases (S-1 and S-2) and is covered with a thin layer of drift sand (D2) in which a distinct $\mathrm{Ah}$ and albic $\mathrm{E}$ has formed (S-3). The Ah is overlain by a thick sheet of drift sand (D-3) in which a prominent podzol has developed (S-4). The prominent development is evidenced by the marked illuvial concentration of $\mathrm{Al}, \mathrm{Fe}$ and $\mathrm{C}$ $\left(\mathrm{Fe}_{\mathrm{p}}, \mathrm{Al}_{\mathrm{p}}\right.$ and $\left.\mathrm{C}\right)$ in the $\mathrm{Bh}$ horizons, as compared to the low values for these compounds in the E horizon (Table 5). Overall Fe losses due to leaching are also very distinct in the $\mathrm{Fe}_{\mathrm{d}}$ values, while the characteristic accumulation of illuvial $\mathrm{Al}$ in the Bh horizon of Podzols clearly shows up in both $\mathrm{Al}_{\mathrm{p}}$ and $\mathrm{Al}_{\mathrm{d}}$ values (see e.g. Buurman, 1985; Lundström et al., 2000).

LWM III is from the centre of the depression (see Fig. 7). Here, the upper horizons of the soil S-1, which is developed in cover sand, exhibit marked load casting. This soil, which is an incipient podzol and has a non-stagnant Bh horizon with abundant biopores, is covered by drift sand that because of its lateral extension towards LWM II must largely date from phase $\mathrm{D}-3$, resting on drift sand that was deposited in open water (phase L-1) and is slightly older (see 0SL dating). In this drift sand a strongly developed Podzol (S-4) has formed, extending from the surface of D-3 downward. Humic substances connected with S-4 migrated into D-3, accumulating as dark brown fibres and, on top of S-1, as a dense brownish layer. In Table 2 a more extensive description of the sedimentary structures is presented, with 7 units or sets being distinguished in the plastic peel monolith (see also Fig. 7b).

Structures in units 3 and 4 indicate conditions of open water during or soon after accumulation. The lower unit in cover sand (7) also reflects some influence of water during or soon after deposition, but on a very minor scale compared to the abovementioned units. Unit 2 typifies dry aeolian accumulation,

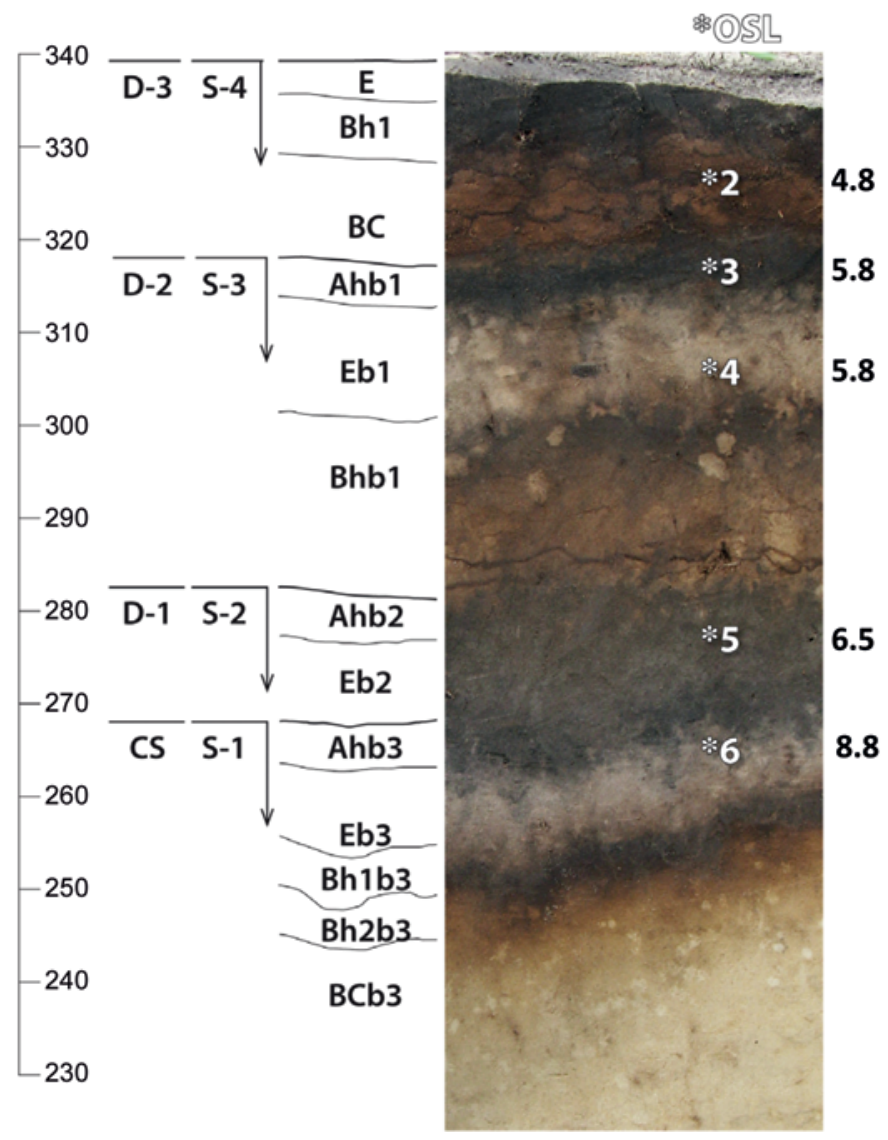

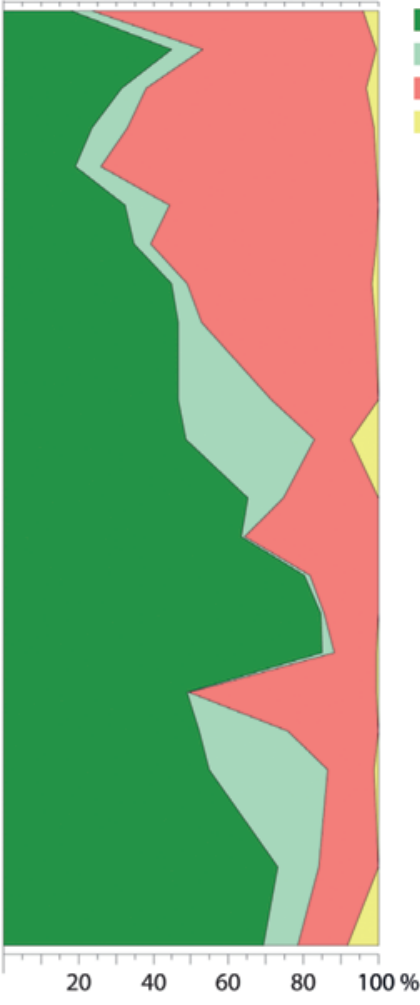

Fig. 5. Section LWM II. Left: soil horizons, soils $(S)$ and aeolian phases $(D) . C S=$ cover sand; * = Location and age of OSL samples. Right: Pollen diagram with percentages of major plant groups (trees, poaceae, ericaceae and other herbs). 
Table 4. Analytical data on profile LWM IV: $a$. chemical data; $b$. grain-size distributions.

a.

\begin{tabular}{|c|c|c|c|c|c|c|c|c|c|c|c|}
\hline Horizon & $\mathrm{cm}$ & $\mathrm{pH} \mathrm{H}_{2} \mathrm{O}$ & $\mathrm{pH} \mathrm{CaCl} 2$ & $\begin{array}{l}\text { EC } \\
(\mu \mathrm{S} / \mathrm{cm})\end{array}$ & $\begin{array}{l}\mathrm{Fe}_{2} \mathrm{O}_{3}-\mathrm{p} \\
(\mathrm{mmol} / \mathrm{kg})\end{array}$ & $\begin{array}{l}\mathrm{Al}_{2} \mathrm{O}_{3}-\mathrm{p} \\
(\mathrm{mmol} / \mathrm{kg})\end{array}$ & $\begin{array}{l}\mathrm{Fe}_{2} \mathrm{O}_{3}-\mathrm{d} \\
(\mathrm{mmol} / \mathrm{kg})\end{array}$ & $\begin{array}{l}\mathrm{Al}_{2} \mathrm{O}_{3}-\mathrm{d} \\
(\mathrm{mmol} / \mathrm{kg})\end{array}$ & C & $\mathbf{N}$ & $\mathrm{C} / \mathrm{N}$ \\
\hline Ah & $0-8$ & 6.29 & 5.81 & 229 & 0.088 & 32.3 & 0.37 & 35.8 & 2.61 & 0.112 & 23.3 \\
\hline $\mathrm{E}$ & $8-13$ & 6.40 & 5.86 & 127 & 0.287 & 13.9 & 0.45 & 15.0 & 0.89 & 0.041 & 21.6 \\
\hline Bh1 & $13-18$ & 6.44 & 5.91 & 145 & 0.297 & 16.3 & 1.21 & 19.9 & 0.65 & 0.032 & 20.7 \\
\hline Bh2 & $18-26$ & 6.29 & 5.96 & 171 & 0.339 & 14.6 & 1.45 & 19.7 & 0.44 & 0.023 & 19.3 \\
\hline $\mathrm{Cg}$ & $>26$ & 6.29 & 5.93 & 186 & 0.305 & 6.40 & 3.32 & 20.1 & 0.08 & 0.006 & 17.6 \\
\hline
\end{tabular}

b.

\begin{tabular}{llllll}
\hline Horizon & Ah & E & Bh1 & Bh2 & Cg \\
$\mathrm{cm}$ & $0-8$ & $8-13$ & $13-18$ & $18-26$ & $>26$ \\
$2,000-1,000 \mu \mathrm{m}$ & 0.0 & 0.0 & 0.1 & 0.0 & 0.1 \\
$1,000-500 \mu \mathrm{m}$ & 0.8 & 0.4 & 0.7 & 1.0 & 0.4 \\
$500-250 \mu \mathrm{m}$ & 20.2 & 20.0 & 17.0 & 15.2 & 12.5 \\
$250-125 \mu \mathrm{m}$ & 59.5 & 67.5 & 63.6 & 57.7 & 69.7 \\
$125-63 \mu \mathrm{m}$ & 12.6 & 10.2 & 13.9 & 17.2 & 15.5 \\
$<63 \mu \mathrm{m}$ & 6.8 & 1.9 & 4.6 & 8.9 & 1.7 \\
\hline
\end{tabular}

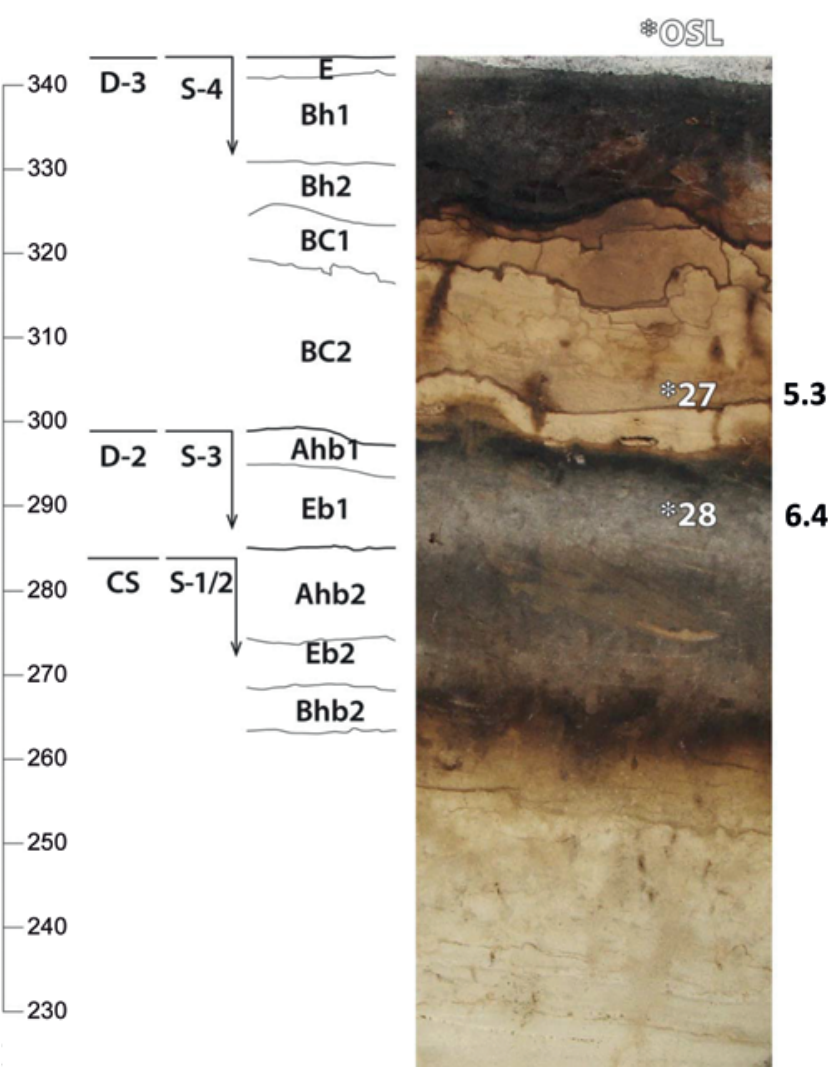

Fig. 6. Section LWM V. Left: soil horizons, soils (S) and aeolian phases (D). $C S=$ cover sand; $*=$ Location and age of OSL samples.

whereas unit 6 represents an intermediate condition (facies type b according to Koster 1988, 2005b). Lastly, the (possible) occurrence of frost cracks in unit 7 would be in conformance with its age, as based on the general stratigraphy, being the Younger Dryas.
LWM IV is close to LWM III and with an identical sedimentary sequence (D-3 with S-4 in its top), but at slightly higher altitude, lacking the distinct load casting (and thus also phase L-1) ( Fig. 8). The composition of the pollen assemblage in the cover sand (with S-1/3) is quite uniform, with only a slight decline of tree pollen and increase of Ericales in the upper centimetres of the Ah horizon. Alnus and Corylus and to a lesser extent Ulmus and Quercus were present in the regional landscape, but ca 20\% Ericales and ca 10\% Poaceae, in combination with about $10 \%$ spores of Lycopodiella inundata point to a local vegetation that best can be described as 'moist heath'. The lower part of the drift sand (D-3) on top of the soil (S-1/3) shows an increase of Ericales in combination with Asteraceae, Jasione montana and Melampyrum, following on an initial phase with lower values. Overall, Ericales increase slightly and tree pollen decline, pointing to at most minor changes in the local vegetation.

The soil in the top of the cover sand (phases S-1/3) is well preserved and characteristic for the Holocene buried hydromorphic podzol widely encountered in the lower parts of the LWM area (see Fig. 1d). It can be described as an incipient hydromorphic podzol, evidenced by bleaching in the Ah/AEh horizon and a slight illuvial accumulation of brownish organic matter in the Bh horizons. In Table 4 chemical data are presented that illustrate the relatively slight accumulation of complexed $\mathrm{Al}$ and $\mathrm{Fe}$ in the Bh. The Fed values evidence the loss of Fe from the original topsoil of which only part is retained as complexed $\mathrm{Fe}$ in the lower horizons. The higher concentrations of $\mathrm{Fe}, \mathrm{Al}$ and $\mathrm{C}$ in the $\mathrm{Ah}$ are clearly to be attributed to the accumulation of organic matter during S-4, as also observed in LWM III.

The Groot Wasmeer and its southern border (Fig. 2b)

LWM VII is a characteristic profile from the southeastern border, where the white sands are very well developed and hold a fair number of peat intercalations (Fig. 9a). The top of these sands and intercalated peat layers is at about $325 \mathrm{~cm}+\mathrm{NAP}$. Locations of OSL samples and results are given in Fig. 9a and Table 3 respectively. For the peat layer an AMS radiocarbon dating was carried out on plant fragments (charred leaves of Calluna and Erica, and Juncus seeds) that were handpicked from the peat. Its age is also given in Table 3. A description of a nearby but slightly different profile is given. 
Table 5. Analytical data on profile LWM V: a. chemical data; b. grain-size distributions..

\begin{tabular}{|c|c|c|c|c|c|c|c|c|c|c|c|}
\hline Horizon & $\mathrm{cm}$ & $\mathrm{pH} \mathrm{H}_{2} \mathrm{O}$ & $\mathrm{pH} \mathrm{CaCl} 2$ & $\begin{array}{l}\text { EC } \\
(\mu \mathrm{S} / \mathrm{cm})\end{array}$ & $\begin{array}{l}\mathrm{Fe}_{2} \mathrm{O}_{3}-\mathrm{p} \\
(\mathrm{mmol} / \mathrm{kg})\end{array}$ & $\begin{array}{l}\mathrm{Al}_{2} \mathrm{O}_{3}-\mathrm{p} \\
(\mathrm{mmol} / \mathrm{kg})\end{array}$ & $\begin{array}{l}\mathrm{Fe}_{2} \mathrm{O}_{3}-\mathrm{d} \\
(\mathrm{mmol} / \mathrm{kg})\end{array}$ & $\begin{array}{l}\mathrm{Al}_{2} \mathrm{O}_{3}-\mathrm{d} \\
(\mathrm{mmol} / \mathrm{kg})\end{array}$ & C & $\mathbf{N}$ & $\mathrm{C} / \mathrm{N}$ \\
\hline$E$ & $0-3$ & 3.81 & 2.95 & 53 & 0.32 & 3.6 & 0.62 & 4.9 & 1.30 & 0.041 & 31.6 \\
\hline Bh1 & $3-8$ & 3.68 & 2.98 & 80 & 0.44 & 17.9 & 0.71 & 20.2 & 2.12 & 0.066 & 32.3 \\
\hline Bh2 & $8-15$ & 3.61 & 3.09 & 111 & 0.61 & 38.9 & 0.95 & 42.2 & 3.67 & 0.130 & 28.3 \\
\hline $\mathrm{BC} 1$ & $15-26$ & 3.84 & 3.42 & 57 & 0.66 & 15.5 & 1.59 & 18.3 & 0.73 & 0.022 & 33.8 \\
\hline $\mathrm{BC} 2$ & $26-42$ & 4.10 & 3.73 & 38 & 0.69 & 14.9 & 2.79 & 19.0 & 0.47 & 0.014 & 34.9 \\
\hline
\end{tabular}

$b$.

\begin{tabular}{llllll}
\hline Horizon & $\mathrm{E}$ & Bh1 & Bh2 & BC1 & BC2 \\
$\mathrm{cm}$ & $0-3$ & $3-8$ & $8-15$ & $15-26$ & $26-42$ \\
$2,000-1,000 \mu \mathrm{m}$ & 0.4 & 0.4 & 0.5 & 0.1 & 0.0 \\
$1,000-500 \mu \mathrm{m}$ & 3.1 & 5.2 & 5.2 & 1.5 & 2.7 \\
$500-250 \mu \mathrm{m}$ & 25.3 & 24.8 & 29.3 & 20.5 & 41.0 \\
$250-125 \mu \mathrm{m}$ & 59.3 & 58.1 & 53.5 & 66.5 & 49.9 \\
$125-63 \mu \mathrm{m}$ & 9.9 & 10.0 & 10.4 & 10.7 & 6.2 \\
$<63 \mu \mathrm{m}$ & 2.0 & 1.5 & 1.1 & 0.8 & 0.3 \\
\hline
\end{tabular}

The cover sand displays a very wavy sub-horizontal lamination with small-scale low-angle cross-lamination, and many fine gravelly layers. In the upper part of this lower unit there appears to be an irregular alternation of somewhat finer and somewhat coarser, more disturbed, layers. The thin layers of coarse sand and fine gravel represent deflation lags. Together, these phenomena point to slight aeolian reworking of the E horizon.
The top of the podzol is eroded by water and marked by its extreme contortion, most probably by load casting (see Fig. 3a, b). The structures in the greyish-white sand on top of the podzol evidence the deposition of this sand in a lake by large scour and fill structures and contorted layers of re-deposited peat (load casting), similar to the top of the underlying podzol. Whether this sand represents drift sand blown into a lake or sand from the lake bank that was reworked by wave action is not clear. From about $320 \mathrm{~cm}+\mathrm{NAP}$ the deposits of this phase L-2 grade into the overlying characteristic 'recent' yellow drift sand.

Pollen data (see Fig. 9b) indicate that Ericales (Calluna) played an important role from the onset of soil formation (the podzol) till the stabilisation of the 'recent drift' sand by forestation. Alnus and Corylus were of minor importance, with highest values in the podzol and gradually declining towards the surface. Fagus pollen, present in low amounts in the whitish sands indicates a Subatlantic age of the lake deposits.
Fig. 7. Section LWM III. Left: soil horizons, soils (S) and aeolian phases (D). CS = cover sand; $*=$ Location and age of OSL samples. Right: plastic peel monolith with units distinguished.

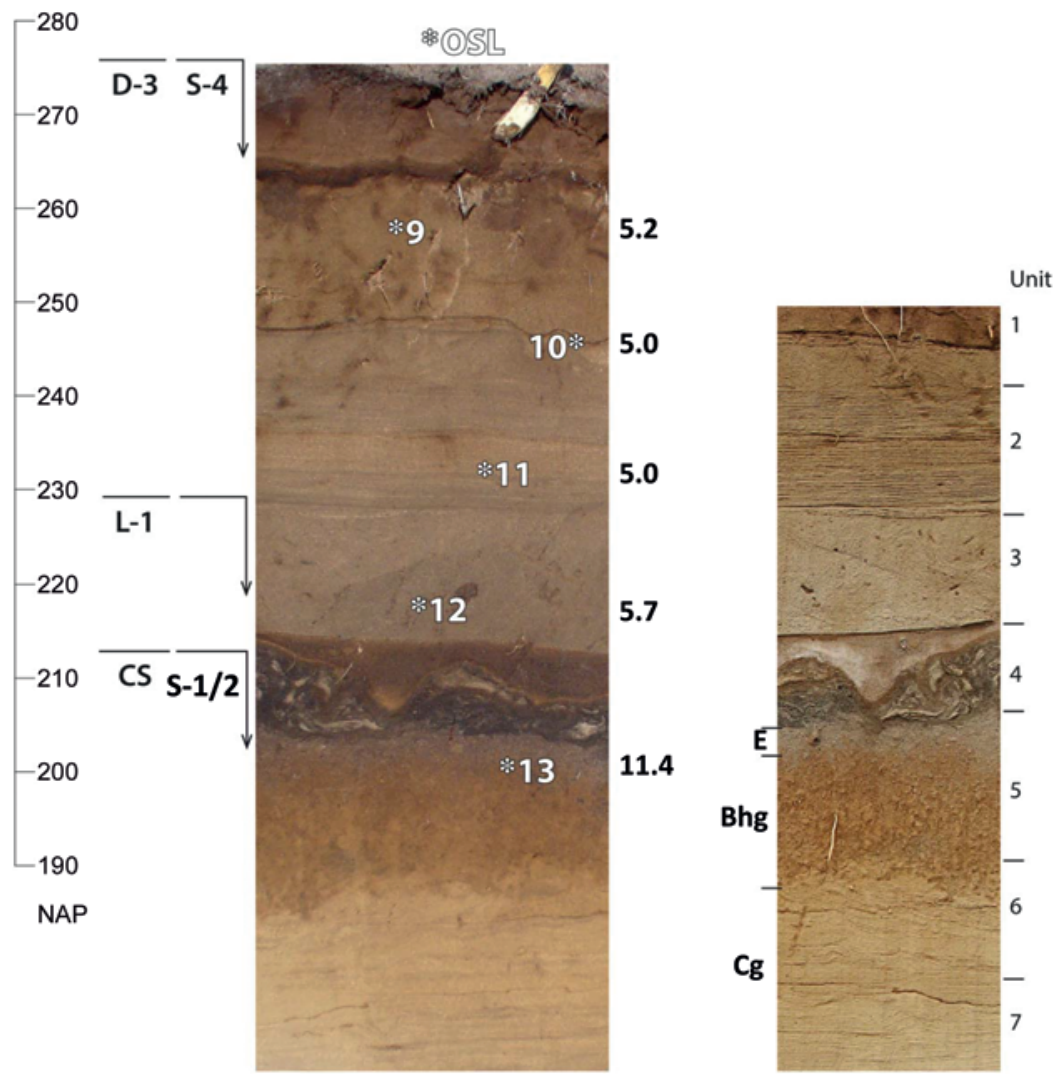




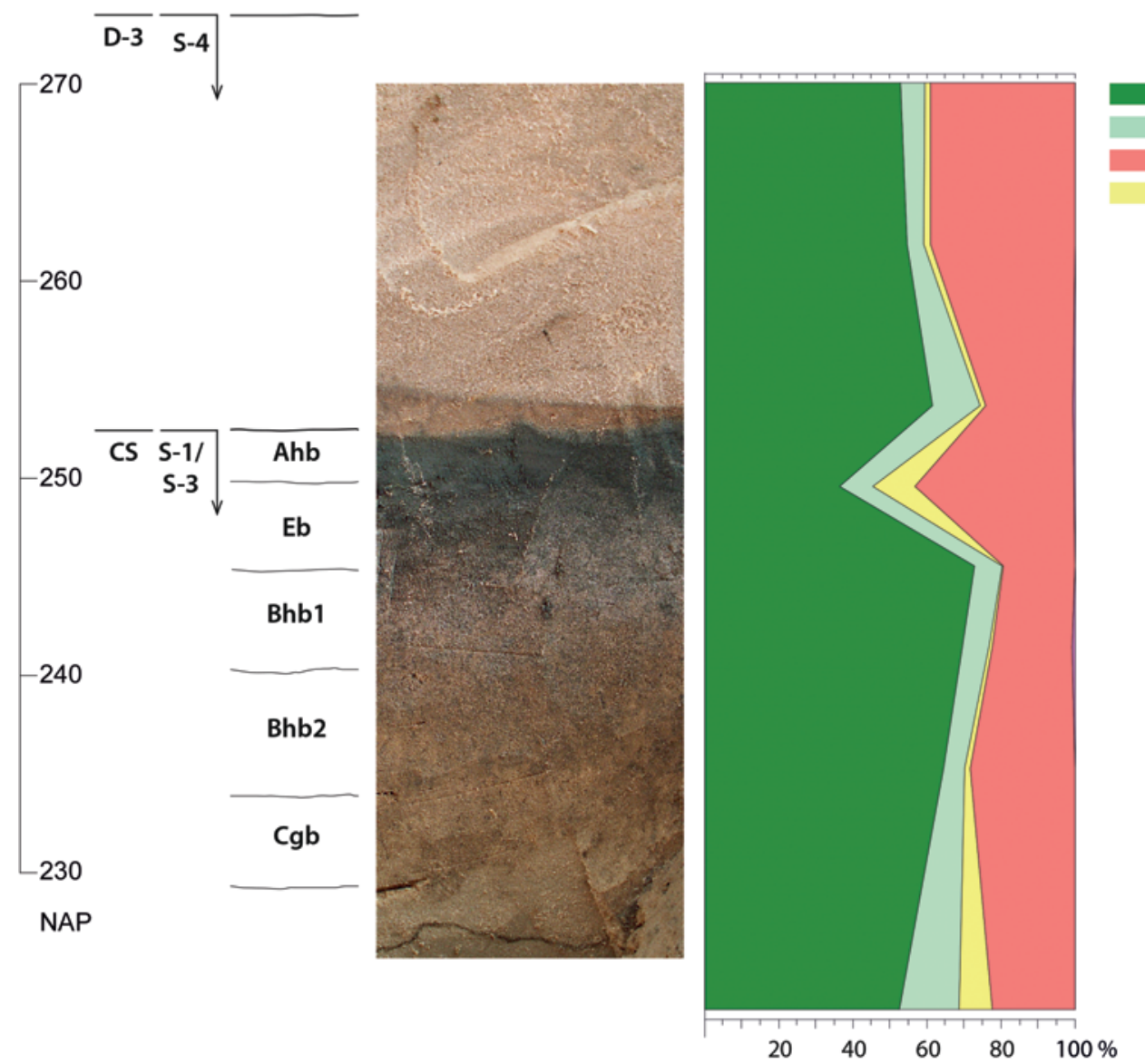

Fig. 8. Section LWM IV. Left: soil horizons, soils (S) and aeolian phases (D). CS = cover sand. Right: Pollen diagram with percentages of major plant groups (trees, poaceae, ericaceae and other herbs).

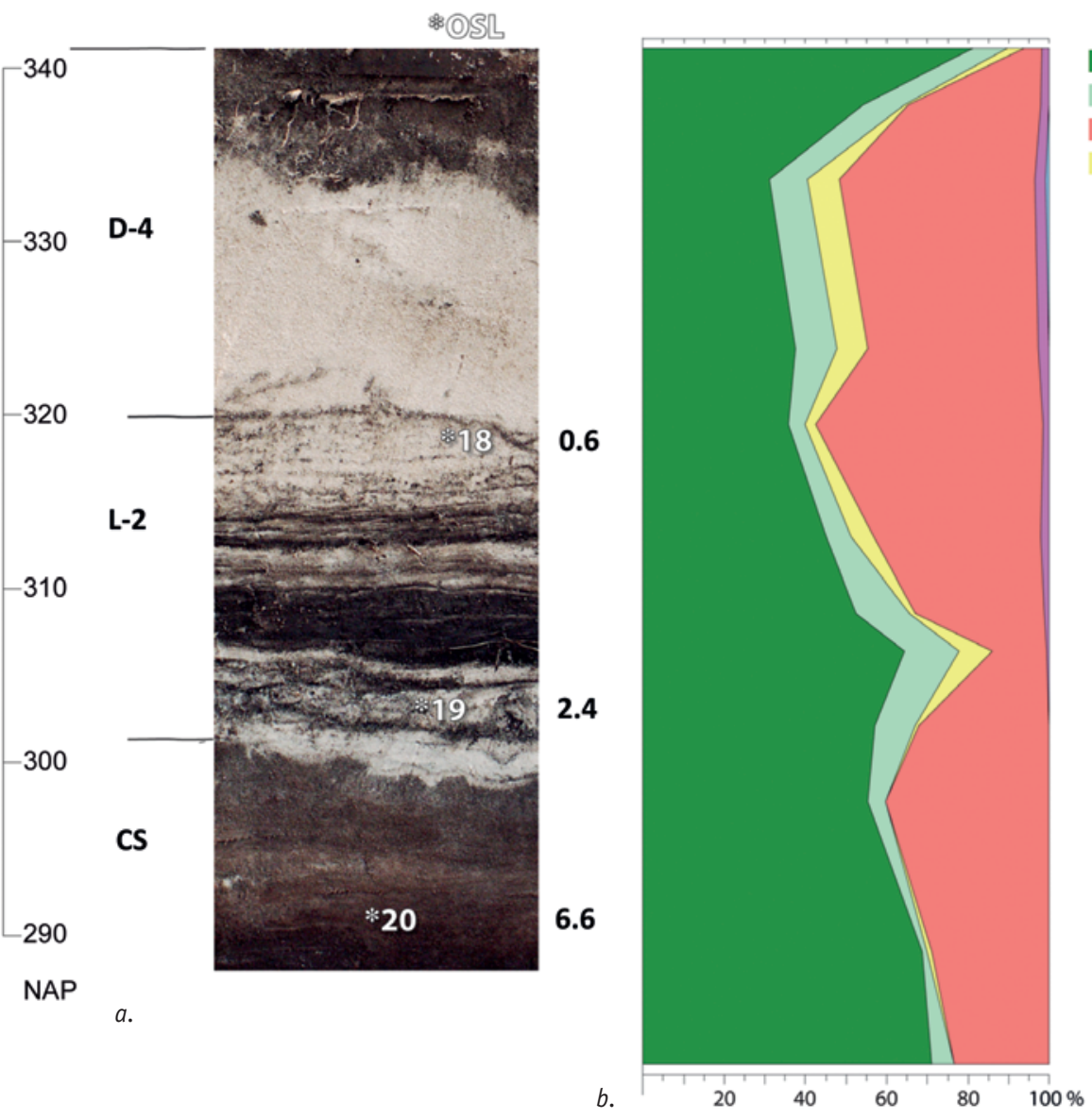

Fig. 9. a. Section LWM VII with location and age of OSL samples, top of podzol in cover sand (CS), lacustrine deposit (L-2) and drift sand $(D-4) ; b$. Pollen diagram with percentages of major plant groups (trees, poaceae, ericaceae, other herbs, cerealia and Fagopyrum. 
Evidence for agriculture is evident in these deposits from the presence (in low quantities) of pollen of anthropogenic indicators (weeds and cereal-type plants) like Artemisia, other Asteraceae, Plantago lanceolata, P. major/media, Fagopyrum and Cerealia (among which Secale).

LWM VI is a profile through cart tracks in the ridge that constitutes the northern border of the Groot Wasmeer. OSL and pollen samples (see Fig. 10) were taken from these tracks. From plastic peel monoliths it became clear that the sandy infill of the tracks was two-phased, the OSL samples being from the latest infill and the pollen samples from both phases (see Fig. 10). The podzol (S-4), in which the cart tracks occur, is in drift sand from phase D-3 that rests on cover sand with a podzol (S1-3).

The pollen record indicates a dominance of Ericales (more than 50\%) with in addition around 30\% tree pollen (most Corylus and Alnus). Pollen of Secale, Fagopyrum and Cannabis pollen point to contemporary agriculture in the region.

\section{Chronostratigraphy}

\section{OSL dose distribution and dating}

The various phases can be dated on the basis of the OSL datings, but these datings need to be handled with care (see e.g. Van Mourik et al., 2010). In sediment that is not affected by bioturbation, the OSL age refers to the time elapsed since deposition. However, in case of bioturbation a sample is composed of a mixture of grains, of which the 'age' may have been more or less reset as a result of post-depositional exposure to light. In case of strong bioturbation, the OSL age may approach the 'time of burial' rather than 'time of deposition'. If only part of the grains were exposed to light due to bioturbation, this will result in a mix of grains with different OSL ages. Such mixing will be reflected by overdispersed dose distributions (see section 'OSL dating').

Although the overdispersion will be damped due to averaging within the $3-\mathrm{mm}$ aliquots each consisting of about 160 grains, additional overdispersion will still be apparent because the OSL signal of each aliquot is dominated by a few grains with large OSL sensitivity. Equivalent-dose distributions will also be overdispersed in cases where light exposure was not sufficient to completely reset the OSL signal in all grains prior to deposition and burial. In aeolian depositional environments as studied here, this is expected to be only relevant for very young deposits, for which remnant doses can be large compared to the burial dose. For the samples investigated here, overdispersion values were around $15 \%$ for most samples. This overdispersion is attributed to spread inherent to the measurement procedure ( $9 \%$ overdispersion in dose-recovery experiment), combined with grain-to-grain variations in dose rate (for these samples estimated to be $\sim 20 \%$ at single-grain level; $10 \%$ for 3-mm aliquots; see Cunningham et al., 2011). These two error yields in combination yield the observed $15 \%$ overdispersion. The three youngest samples show much larger

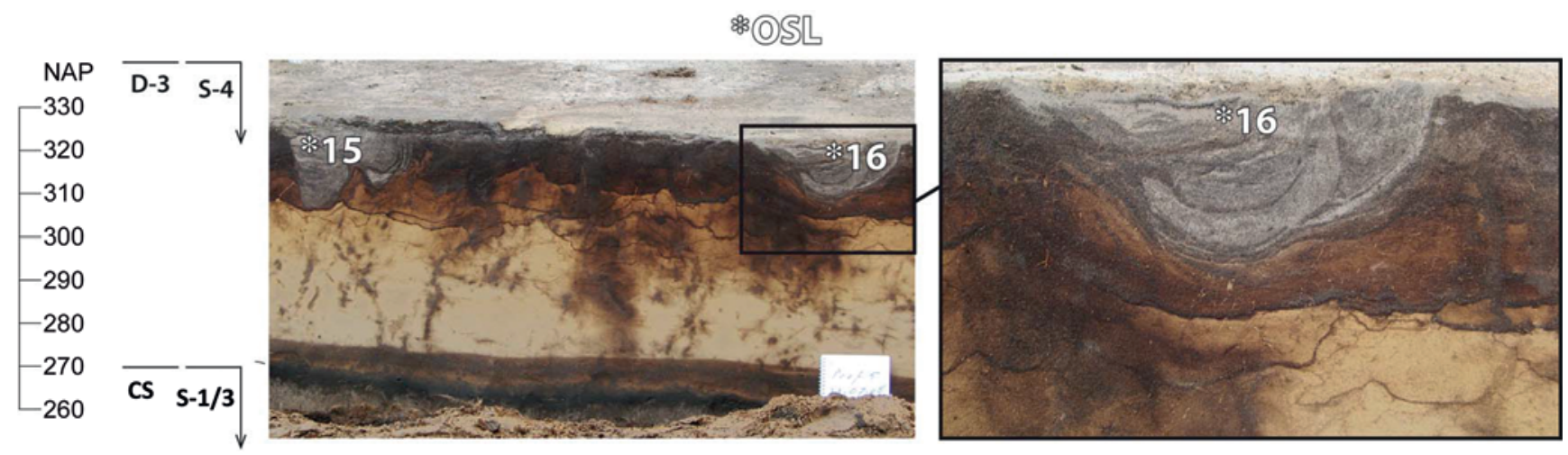

Fig 10. Section LWM VI, with detail of cart track. Left: soil horizons, soils (S) and aeolian phases (D). OSL 15 and 16 are resp. 0.16 and $0.19 \mathrm{ka}$.

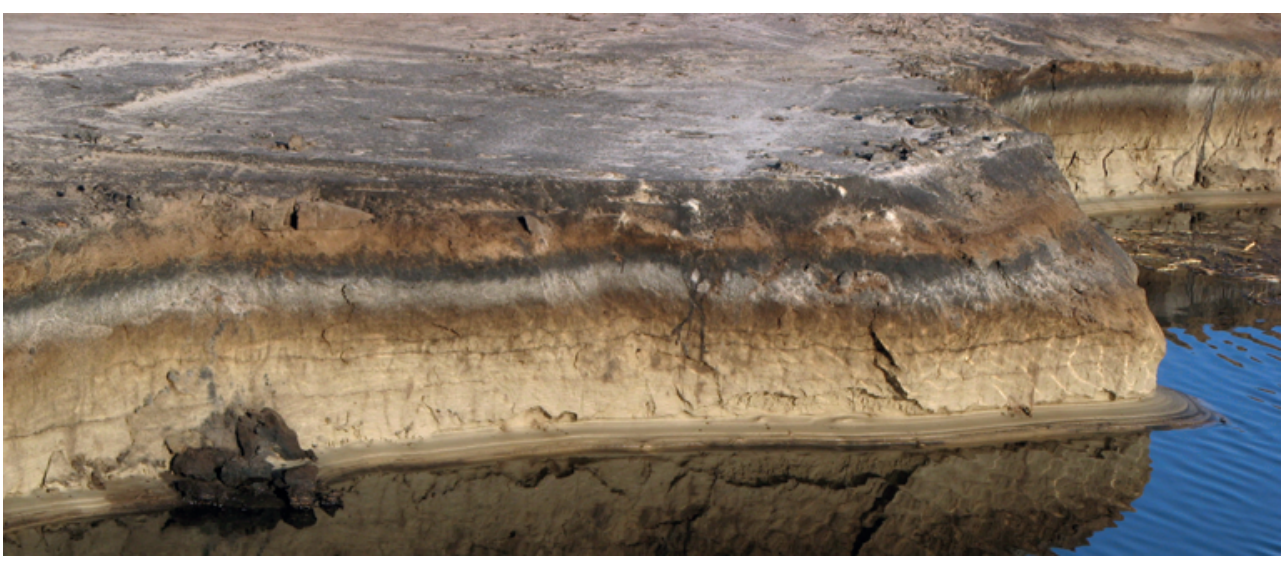

Fig. 11. Well-developed podzol of phases $\mathrm{S}-1 / 3$ in cover sand, buried under drift sand (phase D-3) in central part of Vuilwaterplas. 
overdispersion $(>35 \%)$. This is attributed to incomplete resetting of the OSL signal in some of the grains, or sampling of deposits formed in different periods. For these samples a Minimum Age Model was used to estimate the burial dose of the youngest phase (Galbraith et al., 1999). Examples of the various situations encountered are given in Fig. 12.

For the other samples, only three samples showed overdispersion greater than $16 \%$. This concerned samples LWM II-3 and -5 , and LWM III-13. The latter sample was from near the top of the cover sand unit (Fig. 7), and likely was close to the palaeosurface for a very long time. We attribute the overdispersion (26\%) to incorporation of light-exposed grains through bioturbation. This may have led to a slight underestimation of the actual burial dose and age. Samples LWM II-3 and -5 show a slightly elevated overdispersion (22 and 20\%, respectively). Both samples are taken from weakly developed Ah horizons, where bioturbation is likely to induce some mixing. Moreover, the lower sample is obtained from a thin deposit attributed to drift sand phase D-1. This $10-15 \mathrm{~cm}$ deposit is sandwiched between cover sand and younger drift sand (D-2). Light-exposed grains may have been transported down to the sample position due to bioturbation at the time of soil formation (S-2). On the other hand, bioturbation may have introduced older grains from below. It is therefore not possible to judge whether the true depositional age of D-1 may be slightly younger or older than the OSL age suggests. Thus, the reported age remains the best estimate and any deviations are likely small. Sample LWM II-3 is taken from near the boundary between the drift sands attributed to phases D-2 and -3 . The OSL age is identical to that obtained on the sample below and hence the effect of bioturbation on the age is apparently negligible. Sample LWM II-6 is taken from the Ah horizon in the cover sand soil (S-1). The absence of overdispersion in combination with the well-developed soil suggests that bioturbation may have been rather intense. We suggest that this OSL date is likely to reflect the time of burial of this soil, rather than the time of deposition of the cover sand.

Lastly, while our original OSL ages were expressed in ka (see Table 3), relative to time of sampling (2008), we use year BC or year $\mathrm{AD}$ for the phases distinguished on the basis of these OSL ages, since this allows for easier comparison with ages published in other studies.

\section{The central area (see Fig. 2a for overview)}

In LWM III (Fig. 9), the cover sand is 0SL dated to $11.4 \pm 0.7 \mathrm{ka}$ (Bh horizon). This is in good agreement with other chronological evidence suggesting that it was deposited at least 11,500 years ago (see e.g. Kasse, 2002). The OSL age obtained on the Ah horizon of S-1 in LWM II $(8.8 \pm 0.4 \mathrm{ka})$ is interpreted to reflect the age of burial of the soil (see above). This earliest paleosol is a hydromorphic, more or less incipient podzol, lacking a dense, prominent illuvial Bh horizon and with well-recognisable former
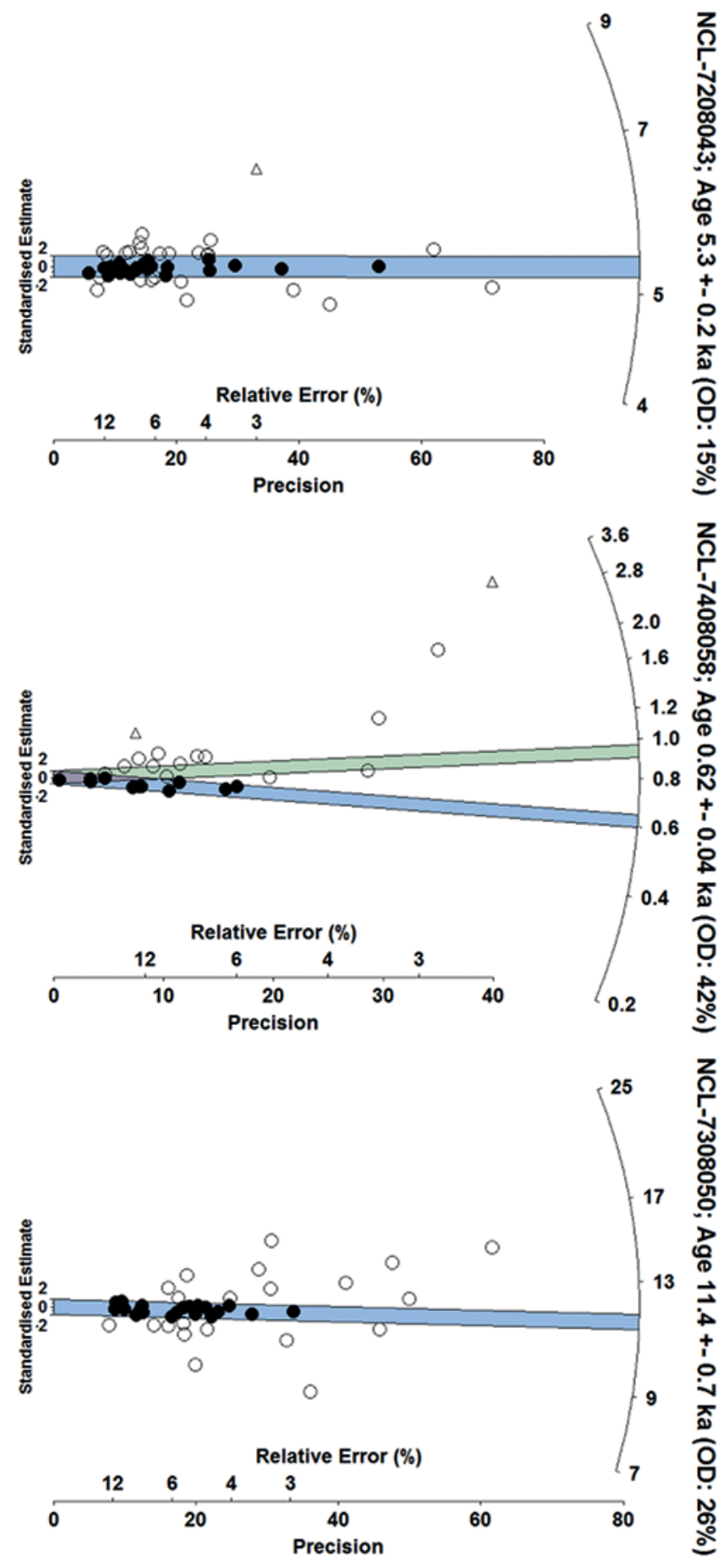

Fig. 12. Radial plots (Galbraith, 1990) show the spread in ages obtained on individual aliquots including their relative error. Uncertainties in equivalent dose estimation are included, errors in dose rate are shared by all aliquots and hence not shown here. Extreme outliers ( $>3$ standard deviations from sample mean) were iteratively removed prior to analysis; these are shown as open triangles. The blue bar shows the age determined for the sample; filled points agree with this estimate within errors (2 sigma). Shown are examples of a sample with normal spread $(A=L W M V-27), a$ poorly-bleached sample ( $B=$ LWM VII-18) with CAM (green) and MAM3 (blue) age indicated, and a sample expected to be affected by bioturbation $(C=$ LWM III-13). For sample NCL-7408058 a high precision estimate at $1.27,0.01 \mathrm{ka}$ was omitted from the graph to enhance readability. 
root channels and bio-macropores throughout. That bioturbation was important is also evidenced by the pollen analysis, which showed that pollen as well as plant macroremains are found down to a depth of 25-30 cm below the top of the paleosol.

As to phase D-3, it is clear that this is a major phase as compared to the phases D-1 and D-2, and involved the deposition of relatively fresh sand (C-material) rather than of reworked soil material (A, E and B horizons). The soil (S-4), developed in this drift sand layer, is marked by intense podzolisation and in its lower horizons still retains sedimentary stratification, evidencing a very low degree of bioturbation. Samples from this drift sand are quite uniform in their OSL age $(4.8 \pm 0.2$ to $5.2 \pm 0.3 \mathrm{ka}$ ) These ages clearly represent the 'time of deposition' and point to a short intensive phase of aeolian deposition around 3,000 BC.

OSL ages also constrain the timing of phases D-1 and D-2. The top of D-1 in LWM II (Ah horizon) has an OSL age of $6.5 \pm 0.4 \mathrm{ka}$, and in LWM $V$ the sand at the base of D-2 (lower E horizon) has an age of $6.4 \pm 0.3 \mathrm{ka}$. The soil phase $\mathrm{S}-2$ is thus constrained to have occurred till at latest about 4,500 BC. Its duration is apparently short considering the limited dimensions of the Ah and E horizon. Other research has also shown that such soil may form in several hundred years only (e.g. Van Mourik et al., 2010). The age of D-1, i.e. the deposition of the drift sand in which S-2 developed, thus can be defined as broadly in between about 4,500 and 6,500 BC, leaving between 3,000-5,000 for the soil phase S-1.

For the dating of D-2 a similar line of reasoning can be followed. In LWM II, the OSL ages for the upper horizons in this $\mathrm{D}$-2 (Ah and E horizon) are 5.8 $\pm 0.3 \mathrm{ka}$. In LWM V bioturbation is less conspicuous and the OSL age (lower part of E horizon) is slightly older $(6.4 \pm 0.3 \mathrm{ka})$. Given the ages obtained for D-3 (around $5 \mathrm{ka}$, see above), this leaves about 1,000 years for soil phase S-3, which seems adequate since this podzol is not strongly developed (see LWM II) and was largely formed in drift sand with a significant component of material derived from podzolised Ah and E horizons.

In LWM III, phase L-1 is represented by the sands directly overlying S-1, for which an OSL age of $5.7 \pm 0.3 \mathrm{ka}$ was obtained. They rapidly grade into sands that were deposited during phase D-3 from about $230 \mathrm{~cm}+\mathrm{NAP}$. The transition from 'lacustrine' (shallow open water) conditions with marked load casting during L-1/early phase D-3 to drier conditions later on dates from about 3,000 BC. Thus, around 3,000 BC the shallow open water in the central depression reached a level of about $230 \mathrm{~cm}$ +NAP. Arguments for truly poorly drained conditions and open water in this depression were also found in the pollen record of LWM IV: in the lower samples of LWM IV, at about $250 \mathrm{~cm}+\mathrm{NAP}$, Lycopodiella inundata occurred, which is characteristic for open, wet sandy habitats and wet heaths (Dorland et al., 2005; Van der Meijden, 2005).
The Groot Wasmeer (see Fig. $2 b$ for overview)

Whereas in the central area D-3 is the latest drift sand phase and soil formation prevails from around 3,000 BC onward, the later history of the Groot Wasmeer clearly is more complex. LWM VII shows that following on the development of a pronounced podzol with dense spodic B and thick albic $\mathrm{E}$ horizon, a lake developed through stagnation on this podzol (phase L-2). Though the lake may already have existed earlier, it is only after phase D-3 (around 3,000 BC), when the ridge that separated the Groot Wasmeer from the central area reached its current elevation, that the lake level may have reached the altitude of about $300 \mathrm{~cm}+$ NAP. Such altitude was needed to flood the border zone of the Groot Wasmeer. The lake must have reached that altitude somewhere around $400 \mathrm{BC}$ (the earliest bleached sand, sample 19) and reached a maximum level of about $325 \mathrm{~cm}+\mathrm{NAP}$ around 1,400 AD. This leaves a period of at least about 5,500 years (from the early Holocene till at least 3,000 BC) for the genesis of the podzol in the central lake area and a further 2,500 years for continued podzolisation in the higher border zone, totalling about 8,000 years for podzolisation prior to the installation of lacustrine conditions in this zone and explaining the strong development of this podzol. Clearly in the southern border zone (LWM VII) drift sand phases D2 and D3 are absent, given the OSL date of $6.6 \mathrm{ka}(4,600 \mathrm{BC})$ for the sand of the albic horizon.

The OSL dating of the lower sandy lake sediment is confirmed by the radiocarbon dating of the intercalated peat layer. Around $1,400 \mathrm{AD}$ the lacustrine sediments were covered by terrestrial drift sands, evidenced by the yellowish colour of the latter sands that is due to thin iron coatings, which disappear upon deposition in aquatic conditions. The altitude of this transition is about $325 \mathrm{~cm}+\mathrm{NAP}$, which is the highest lake level found in this Groot Wasmeer area and corresponds with the highest altitude of the lacustrine deposits to the N. Interestingly, it is precisely at this altitude and in this transitional zone that cart tracks were found with clear load casting and covered by the recent aeolian sands close to LWM VII. Based on the datings of LWM VII these cart tracks can be dated as ca 700 years old, i.e. from the 14th to 15th century AD. This conforms to the age of the various early roads in this area, including the Oude Postweg, which is known to roughly date from that period (Groeneveld, 2001).

In LWM VI multiphased cart tracks were visible that are connected with the large complex of cart tracks to the NE and E, of which the cart track near LWM VII also forms part. Though the youngest phase of infill was OSL dated at around $1830 \mathrm{AD}$, the pollen data show that the earlier phases contain hemp and buckwheat pollen, pointing to an at earliest Late Mediaeval formation of the tracks (Bieleman, 1992).

The later drift sands to the $S$ of the Groot Wasmeer clearly belong to the 'recent drift sands' (phase D-4), lacking significant soil formation. Moreover, the adjacent area to the SW is known 
from early maps as an active drift sand area and these sands typically belong to the classic recent drift sands (see section 'The Laarder Wasmeren area').

\section{Discussion}

\section{Past heathland and woodland vegetation}

Most striking is the predominance of open ericaceous vegetation from very early in the Holocene on. In fact, the earliest Holocene soil (S-1, LWM II), whose burial by drift sand (D-1) occurred around 6,500 BC, i.e. during the Boreal, already had a vegetation dominated by Calluna and Poaceae, following on an early phase in which tree species dominated. We observed in all profiles studied that later on ratios of arboreal to non-arboreal pollen rather fluctuate, though the overall trend is of a predominance of heathland and a decline of tree pollen over time, the only relatively stable species being Alnus. The latter might be attributed to the regional occurrence of poorly drained marshy areas or even open water, whether due to high groundwater or to stagnation on an impervious podzol.

As described in section 'The Laarder Wasmeren area', in this region agriculture is assumed to have started during the Middle Neolithic Funnel Beaker culture (roughly 3,000 BC), but to have had limited impact on the vegetation, which was described by De Smidt (1975), Casparie \& Groenman-van Waateringe (1980), and Groenman-van Waateringe (2010) as being dominated by trees based on palynological studies. These authors concluded for example that it was only during the Bronze Age (2,000-800 BC) that the earlier, Neolithic 0ak-Lime forest was gradually transformed into 0ak-Birch forest and heath dominated by Ericaceae became more prominent. However, our results for the LWM area do not conform to such vegetation history and the presumed late origin of open ericaceous vegetation.

It is only in the lacustrine sands of the Groot Wasmeer (of which the earliest strata date back to about 400 years BC) that we found significant amounts of pollen from taxa (weeds and cerealia) that can be linked to agriculture. In D-2 and D-3/S3 and S-4, we found such pollen only incidentally and in very low amounts, suggesting that earlier farming played a very minor role in the vicinity of the LWM area. Nevertheless, the major drift sand phase D-3 around 3,000 BC strikingly coincides with the first intensive land use that in this region ('het Gooi') dates from the Late Neolithic (Wimmers et al., 1993), suggesting a causal relation between this early agricultural phase and the contemporary land degradation. Additionally, this coincidence suggests that wind erosion and drift sand deposition were most probably linked to overgrazing and burning, rather than farming.

Such explanation - farming - is even more unlikely for the earlier, less intensive drift sand phases D-1 and D-2, and for the presence of open herbaceous vegetation in the pre-agricultural period (e.g. before 3,000 BC). Moreover, there is indeed no archaeological evidence for significant early agriculture in 'het Gooi' and adjacent parts of the Netherlands. The early dominance of heathland vegetation in the LWM area and wind erosion leading to active drift sand, even though of limited dimensions, are thus in clear disagreement with the previous studies on the vegetation history of 'het Gooi' by Wimmers et al. (1993) and Casparie \& Groenman-van Waateringe (1980), as well as with the more general ideas about the Early Holocene vegetation development on Pleistocene deposits of the Central and Western Netherlands (e.g. Van Geel et al., 1981; De Mulder et al., 2003; Louwe Kooijmans, 2012).

It should be emphasised, that the earlier results on the vegetation history of 'het Gooi' were based on studies of samples taken from soils underneath burial mounds, including mounds near the LWM area, and not from well dated profiles with a complex stratigraphy such as studied by us. Moreover, Van Geel \& Bos (2007) also found similar evidence for early open herbaceous vegetation to the west of 'het Gooi', whose origin natural or anthropogenic - remained obscure. Lastly, Vera (1997; see also Whitehouse and Smith, 2010) considers herbivores to have been responsible for the presence of parkland landscapes preventing the development of closed forests in the Holocene, but he does not refer to the activation of drift sand. Unfortunately, the current data are insufficient to decide on a natural origin (large herbivores) or Mesolithic anthropogenic origin of the earliest heathland vegetations and drift sands.

\section{Paleohydrology}

In the central depression, clear evidence was found for the occurrence of shallow open water before and around 3,000 BC, at maximum reaching an altitude of about $230 \mathrm{~cm}+$ NAP. Previous research thus far did not provide indications for the former existence in or near the LWM area of groundwater-fed lakes or marshes in early historic or prehistoric times (Ruegg, 1995; Van Leerdam et al., 2010). Moreover, the low sea level during the earlier Holocene would likely preclude a contemporary occurrence of a high groundwater level, i.e. about $2.30 \mathrm{~m}+\mathrm{NAP}$. At first sight, therefore, stagnation of water on an impermeable podzol seems the most likely explanation for the early presence of open water. However, such explanation must be rejected given the observed properties of the soil formed during phase S-1 and slightly later phase S-2.

The hydromorphic soil in the depression had an incipient $\mathrm{Bh}$ horizon with common macropores and was relatively well structured, thus precluding water stagnation because of its high permeability. Outside the depression, the soil from S-1/2 was less hydromorphic, but also lacked a distinct potentially stagnative spodic horizon and had common macropores, and for that reason lateral surface flow towards the depression during rainfall events was also very unlikely to occur. For true stagnation, a strongly developed and dense spodic B is required, preferentially with a placic horizon. This is corroborated by the 
observations on modern fens, which are limited to areas with podzols that have such strongly developed and dense spodic horizons (e.g. the Groot Wasmeer). It is further supported by a study of the LWM area that aimed at establishing boundary conditions for restoration of the former fens (Cammeraat et al., 2008). This study showed that only for such rather extreme podzols the saturated conductivity (Ksat) is low enough to induce stagnation (Ksat $<1 \mathrm{~cm} /$ day), whereas Ksat values for rather incipient podzols like those of $S-1 / 2$ are such (values >>10 cm per day) that even significant temporary stagnation during major rainfall events must be excluded and indeed was not observed in the past years. Lastly, the vegetation as reconstructed from the pollen data is one of permanent open water. In summary, the open water in the depression must be attributed to a high groundwater level, reaching a maximum altitude of about $230 \mathrm{~cm}+\mathrm{NAP}$, falling to lower values prior to phase $\mathrm{D}-3$, i.e. around 3,000 $\mathrm{BC}$, to never reach that altitude again. The question then is whether this is truly in conflict with the available information on the paleohydrology of het Gooi, which at closer look is not the case.

From the studies by Cohen (2005) and Bos (2010) on the Holocene of the Vecht area some indications for a potentially higher former groundwater level can be inferred: a relatively high groundwater level might be expected for the period in which sea level was already nearing its current altitude and the Holland-peat area to the west was not yet dissected and drained by rivers, such as the Vecht and the Angstel. The resulting poor drainage may have induced a significant backward rise of the groundwater level in the adjacent ridges, e.g. 'het Gooi', as is also suggested by Bos et al. (2009). Such conditions existed from roughly between 3,500 till 1,500 BC, whereas from that time on the Holland peat became dissected and the drainage of 'het Gooi' most likely improved (see also Van Geel \& Bos, 2007; Vos et al., 2011).

A relatively high groundwater level is also assumed by Wimmers \& Van Zweeden (1992), who state that the boundary between dry and wet areas, the latter evidenced by the occurrence of peat and truly hydromorphic podzols, reached a maximum altitude of about $3 \mathrm{~m}+\mathrm{NAP}$. However, their reconstruction is rather tentative, since they do not distinguish between peat formed as a result of stagnation on an impervious podzol and true groundwater dependent peat, and their evidence is fragmental. Moreover, they provide no indication as to the exact period in which such high level was reached.

A final remark concerns the potential attribution of the temporary high groundwater level to climatic conditions, i.e. a very wet period, or to deforestation resulting in lesser evapotranspiration and thus a larger net precipitation surplus. As to the first, in the climatic records from NW-Europe indications for an exceptionally wet period around 3,000 BC have never been observed (e.g. Davis et al., 2003; Blaauw et al., 2004). As to deforestation, such cause cannot explain the decline of the groundwaterlevel since 3,000 BC, which clearly would be in conflict with such hypothesis. We conclude therefore that these alternative hypotheses must be rejected as explanation for the temporary high groundwaterlevel around $3,000 \mathrm{BC}$.

\section{Soil formation and its timing}

During the various soil forming phases the dominant process was podzolisation, but its degree varied. The latter most likely results from differences in length of the soil forming period and the nature of the parent material (reworked C-material or previously podzolised sand), as for example demonstrated by the differences in expression of podzolic features in LWM II (see also Fig. 5).

Even during the earliest soil phase S-1 podzolisation is already evident, with clear horizon differentiation and the development of distinct $\mathrm{E}$ and $\mathrm{Bh}$ horizons where soils were relatively well drained (II and V). The soils concerned would indeed classify as rather incipient veldpodzols (Dutch system, De Bakker \& Schelling, 1966) or Carbic Podzols (FA0, 1998). Where soil formation was more or less continuous during the early phases (S-1/3), such as in LWM III, IV and VI, and was only seriously interrupted around 3,000 BC by deposition of the drift sand of phase D-3, under relatively poorly drained conditions (LWM III and IV) a distinct veldpodzol/Carbic Podzol developed (see Fig. 11). With good drainage this podzol is even prominent though still does not have a strongly developed and dense spodic horizon (e.g. LWM V).

Results for LWM II show that within a period of about 1,000 years a podzol with well-differentiated horizons (see Fig. 5, S-3) developed in drift sand that at least partly consisted of C-horizon derived sand. This podzol was buried around 3,000 BC, i.e. it already existed prior to the Late Neolithic. A similar rapid development of a podzol has also been observed elsewhere (Van Mourik et al., 2010; Koster, 1978; Castel, 1991), particularly where the parent material consists of partially or completely podzol-derived sand (i.e. reworked soil material) (see also Sevink \& Waal, 2010).

As to the timing of the onset of podzolisation, Feijen (2003) gave an excellent overview of the existing opinions. The general concept is that distinct podzols only developed upon serious and prolonged degradation of the forest vegetation into heathland and date back to (at earliest) the Late Neolithic or the Bronze Age. Louwe Kooijmans (1995) for example stated: 'The Bronze Age is also the period of serious soil degradation. Brown Forest Soils turned into Humus Iron Podzols (Waterbolk, 1964). Woodland changed into heathland, documented by the pollen content of the fossil soils below the Bronze Age barrows and the sods with which these were built (Casparie \& Groenmanvan Waateringe, 1980).' The related shift in vegetation is dated at about 2,500 BC.

The onset of podzolisation in the LWM-area is distinctly earlier: the age of the S-1 soil - an incipient podzol - already is 
older than 4,000 BC, and the distinct podzol in LWM V, for example, already existed around 4,000 BC. Moreover, the change from woodland into heathland occurred much earlier: around $6,500 \mathrm{BC}$. Our observations thus suggest that both vegetation and soil transitions in at least this part of the Netherlands were much more varied in space and time, and depended on such factors as slight differences in parent material and in the timing and intensity of prehistoric land use.

\section{General discussion and conclusions}

The distinguished phases in deposition of drift sand and soil formation, and their timing are summarised in Fig. 13. In the aeolian sands of the LWM area, around 6,000 BC soil acidification had already proceeded to such extent that podzolisation started. However, early soils formed were still incipient podzols (weak contrast between $\mathrm{E}$ and Bh horizons, slight illuvial accumulation of organic matter in the Bh horizon). True podzols, i.e. soils with distinct albic and spodic horizons meeting the criteria for their classification as Podzols (FA0, 1998), already existed around 4,000 BC. The soils developed under vegetation that was predominantly ericaceous. In places, trees like Alnus and Corylus occurred, most likely on wetter places, and sometimes grasses (Poaceae) formed an important component. Thus

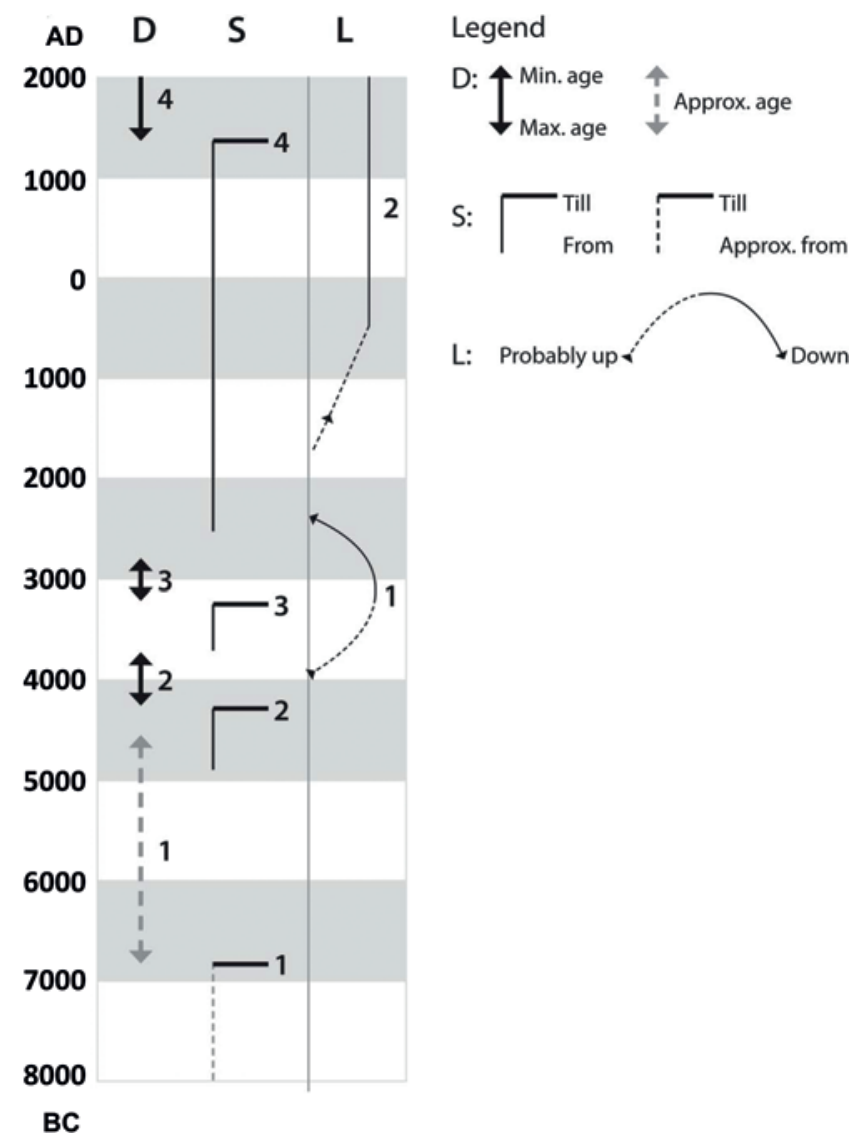

Fig. 13. Summary of phases distinguished in the LWM area and their age in calendar years $(D=$ drift sand; $S=$ soil formation; $L=$ lake or open water $)$. from around 6,000 BC onwards, the overall aspect of the local landscape was one of a heathland with pulses of drift sand deposition. It should be stressed that for podzols with a dense and stagnative spodic horizon a prolonged period of soil formation was needed, which at least partly included phase S-4.

The magnitude of the drift sand pulses increased from very local and of limited dimensions prior to the Late Neolithic (D-1 and $D-2)$, through a true area-wide pulse (D-3) in the Late Neolithic (around 3,000 BC), to a major regional phase from the $14^{\text {th }}$ to $15^{\text {th }}$ century AD onwards (D-4). The earliest drift sand pulse dates back to around 4,500 BC or even earlier. For the early pulses, the traditional arguments of farming and intensive grazing leading to soil degradation do not hold, since signs for such activities do not exist in both the pollen records and the archaeological record (before around 3,000 BC). Nor can the pulses be linked to adverse climatic conditions, a theory put forward in some studies (e.g. Riksen et al., 2006).

Our results are much more in line with recent studies on multiphased and early drift sand pulses such as the study by Willemse \& Groenewoudt (2012). These studies demonstrate that in fragile aeolian sand landscapes even during the Mesolithic and early Neolithic slight disturbance led to drifting sand. However, these early drift sands mostly concern river dune landscapes, which inherently are less stable than the inland cover sands, given the continuous supply of fresh sand to the flood plains.

In this context the question arises whether the higher grounds of 'het Gooi', which formed a kind of relatively dry peninsula in the poorly drained Holocene of the western and central Netherlands (see e.g. Vos et al., 2011), acted as a preferred and thus more densely populated settling area for Late Mesolithic and Neolithic peoples. This might explain both the early disappearance of a closed forest and dominance of ericaceous heathland, and the truly very early land degradation and associated drift sand pulses. The fact that the first Neolithic period with more intensive land use, evidenced by the rather abundant occurrence of archaeological remains, in particular burial mounds (the Late Neolithic, see e.g. Colaris, 1998), is indeed associated with an area-wide drift sand pulse (D-3), forms an argument for such hypothesis.

Whatever the causes are, our results demonstrate, in line with other recent studies, that in the Netherlands the midHolocene transition of forest to heathland and the drift sand pulses exhibit a much larger temporal variability than was generally assumed. They also show that the LWM-area holds a hitherto unknown, but highly valuable and complex geoarchive, providing unique information on the Holocene history of 'het Gooi'. 


\section{Acknowledgements}

We are particularly indebted to the Goois Natuurreservaat (GNR), the Hoogheemraadschap Amstel, Gooi en Vechtstreek, and the Provincie Noord-Holland. They generously gave substantial financial support for the research and thus enabled us to execute a truly multidisciplinary study of the Laarder Wasmeren area. That study confirmed the presence of an exceptional geological archive, which has largely been conserved thanks to the careful execution of the sanitation operation. Thanks are further due to Paul Ubbink, Dick Landsmeer en Poul Hulzink, all from GNR, for their generous help and interest in our research.

Colleagues from the University of Amsterdam include Geert van der Plas, and Casper Romkes, who studied the pollen sections under supervision of Bas van Geel, Annemarie Philip who prepared the pollen samples, and Jan van Arkel whose help with the illustrations was valuable. Leo Hoitinga and Leen de Lange executed the chemical and particle size analyses. Erik de Boer helped with the production of the pollen diagrams. Lastly, Martin Vlaming, whose huge experience with the soils and sediments in the area was of great help, aided us in the study of the various sections and production of the soil monoliths. Janrik van den Berg, from the University of Utrecht, helped with the production of the soil monoliths. Candice Johns and Alice Versendaal from the Netherlands Center for Luminescence Dating (TU Delft) are thanked for luminescence dating, sample preparation, measurement and analysis.

\section{References}

Ballarini, M., Wallinga, J., Murray, A.S., Van Heteren, S., Oost, A.P., Bos, A.J.J. \& Van Eijk, C.W.E., 2003. Optical dating of young coastal dunes on a decadal time scale. Quaternary Science Reviews 22: 1011-1017.

Ballarini, M., Wallinga, J., Wintle, A.G., \& Bos, A.J.J., 2007. A modified SAR protocol for optical dating of individual grains from young quartz samples. Radiation Measurements 42: 360-369.

Bateman, M.D. \& Godby, S.P., 2004. Late-Holocene Inland Dune Activity in the UK: A case study from Breckland East Anglia. The Holocene, 14: 579-588.

Beug, H., 2004. Leitfaden der Pollenbestimmung für Mitteleuropa und angrenzende Gebiete. Verlag Dr. Friedrich Pfeil, München, 542 pp.

Bieleman, J., 1992. Geschiedenis van de landbouw in Nederland 1500-1950. Boom, Meppel/Amsterdam, $423 \mathrm{pp}$.

Blaauw, M., Van Geel B., \& Van der Plicht J., 2004. Solar forcing of climatic change during the mid-Holocene: indications from raised bogs in the Netherlands. The Holocene 14: 35-44.

Bos, I.J., 2010. Distal delta plain successions. Architecture and lithofacies of lake fills and organics in the Holocene Rhine-Meuse delta, the Netherlands. Ph.D. thesis Utrecht University, $221 \mathrm{pp}$.

Bos I.J. Feiken H., Bunnik F. \& Schokker J., 2009. Influence of organics and clastic lake fills on distributary channel processes in the distal Rhine-Meuse delta (the Netherlands). Palaeogeography, Palaeoclimatology, Palaeoecology 284: 355-374.
Buurman, $\boldsymbol{P} ., 1985$. Carbon/sesquioxide ratios in organic complexes and the transition Albic-Spodic Horizon. Journal of Soil Science 36: 255-260

Cammeraat L.H., Sevink J. \& Vlaming M., 2008. Doorlaatbaarheidbepalingen podzol B Laarder Wasmeren, IBED Rapport in opdracht van Waternet (Amsterdam), $4 \mathrm{pp}$.

Casparie, W.A. \& Groenman-van Waateringe, W., 1980. Palynological Analysis of Dutch Barrows. Palaeohistoria 22: 7-65.

Castel, I.I.Y., 1991. Late Holocene aeolian drift sands in Drenthe (the Netherlands). Ph.D. thesis University of Utrecht, Netherlands Geographical Studies 133, $156 \mathrm{pp}$.

Castel, I.I.Y., Koster, E.A. \& Slotboom, R.T., 1989. Morphogenetic aspects and age of Late Holocene aeolian drift sands in Northwest Europe. Zeitschrift für Geomorphologie 33: 1-26.

Cohen, K.M., 2005. 3D Geostatistical interpolation and geological interpretation of paleo-groundwater rise in the Holocene coastal prism in the Netherlands. In: Giosan, L. \& Bhattacharya, J.P. (eds): River Deltas - Concepts, models, and examples. SEPM Special Publication 83: 341-364.

Colaris, W., 1998. Natuur van het Gooi - Kansen voor duurzaam behoud. Ph.D. thesis University of Amsterdam: $420 \mathrm{pp}$.

Cunningham, A.C., Bakker, M.A.J., Van Heteren, S., Van der Valk, B., Van der Spek, A.J.F., Schaart, D.R. \& Wallinga, J., 2011. Extracting storm-surge data from coastal dunes for improved assessment of flood risk. Geology 39, 11: 1063-1066.

Cunningham, A.C. \& Wallinga, J., 2010. Selection of integration time-intervals for quartz OSL decay curves, Quaternary Geochronology 5: 657-666.

Cunningham, A.C., Wallinga, J. \& Minderhoud, P.S.J., 2011. Expectations of scatter in equivalent-dose distributions when using multi-grain aliquots for OSL dating. Geochronometria 38: 424-431.

Davis, B.A.S., Brewer, S., Stevenson, A.C. \& Guiot, J., 2003. The temperature of Europe during the Holocene reconstructed from pollen data. Quaternary Science Reviews 22: 1701-1716.

De Bakker, H. \& Schelling, J., 1966. Systeem van bodemclassificatie voor Nederland: de hogere niveaus. Pudoc (Wageningen), 217 pp.

De Mulder, E.F.J., Geluk, M.C., Ritsema I.L., Westerhoff W.E. \& Wong, T.E. (eds). 2003. De ondergrond van Nederland (Geologie van Nederland 7). Wolters-Noordhoff (Groningen/Houten), $379 \mathrm{pp}$.

Derese, C., Vandenberghe, D., Eggermont, N., Bastiaens, J., Annaert, R. \& Van Den Haute, P., 2010. A medieval settlement caught in the sand: optical dating of sand-drifting at Pulle (N Belgium). Quaternary Geochronology 5: 336-341.

De Smidt, J.T., 1975. Nederlandse heidevegetaties. Thesis Universiteit Utrecht, $98 \mathrm{pp}$.

Dijkmans, J.W.A., Wintle, A.G. \& Mejdahl, V., 1988. Some thermoluminescence properties and dating of aeolian sands from the Netherlands. Quaternary Science Reviews 7: 349-355.

Dijkmans, J.W.A. \& Wintle, A.G., 1991. Methodological problems in thermoluminescence dating of Weichselian cover sand and late Holocene drift sand from the Lutterzand area, E Netherlands. Geologie en Mijnbouw 70: 21-33.

Dijkmans, J.W.A., Van Mourik, J.M. \& Wintle, A.G., 1992. Thermoluminescence dating of aeolian sands from polycyclic soil profiles in the Southern Netherlands. Quarternary Science Reviews 11: 85-92.

Dimbleby, G.W., 1985. The palynology of archaeological sites. Academic Press, (London), $176 \mathrm{pp}$. 
Dorland E., Hart M. A. C., Vermeer M. L. \& Bobbink R., 2005. Assessing the success of wet heath restoration by combined sod cutting and liming. Applied Vegetation Science 8(2): 209-218.

Duller, G.A.T., 2003. Distinguishing quartz and feldspar in single grain luminescence measurements. Radiation Measurements 37: 161-165.

Fanta, J. \& Siepel, H., 2010. Inland Drift Sand Landscapes. KNNV Publishing, Zeist, the Netherlands, $384 \mathrm{pp}$.

Fægri, K. \& Iversen, J., 1989. In: Fægri, K., Kaland, P.E. \& Krzywinski, K. (eds): Textbook of Pollen Analysis, fourth ed. Wiley and Sons, New York, 328 pp.

FAO, 1998. World Reference Base for Soil Resources. World Soil Resources Reports 84. Rome. International Society of Soil Science.

Feijen J.M., 2003. Oak, king of villein?: is the common oak (Quercus robur and Q. petraea) an anachronism in the Dutch forests?: a literature study. M.Sc. thesis WUR, Wageningen, $99 \mathrm{p}$.

Folk, R.L. \& Ward, W.C., 1957. Brazos river bar: a study in the significance of grain-size parameters. Journal of Sedimentary Petrology 27: 3-26.

Galbraith, R.F., 1990. The radial plot - graphical assessment of spread in ages. Nuclear Tracks and Radiation Measurements 17: 207-214.

Galbraith, R.F., Roberts, R.G., Laslett, G.M., Yoshida, H. \& Olley, J.M., 1999. Optical dating of single and multiple grains of quartz from Jinmium rock shelter, northern Australia: Part I, experimental design and statistical models. Archaeometry 41: 339-364.

Groeneveld J., 2001. Hoofdwegen in en rond Eemnes door de eeuwen heen. Historische Kring Eemnes, jaargang 23, nr. 3: 141-155.

Groenman-van Waateringe, W., 2010. Man and vegetation on the Veluwe in six time slices. In: Fanta, J. \& Siepel, H. (eds): Inland Drift Sand Landscapes. KNNV Publishing (Zeist) the Netherlands: 49-64.

Heidinga, H.A., 1984. Indications of severe drought during the 10th century AD from an inland dune area in the Central Netherlands. Geologie en Mijnbouw 63: 241-248.

Heidinga H.A., 2010. The birth of a desert; the Kootwijkerzand. In: Fanta, J. \& Siepel H. (eds): Inland drift sand landscapes. KNNV Publishing (Zeist) the Netherlands: 65-81.

Hilgers, A., Murray, A.S., Schlaak, N. \& Radtke, U., 2001. Comparison of quartz OSL protocols using Lateglacial and Holocene dune sands from Brandenburg, Germany. Quaternary Science Reviews 20: 731-736.

Hilgers, A., 2007. The chronology of Late Glacial and Holocene dune development in the northern Central European Lowland reconstructed by optically stimulated luminescence (OSL) dating. Thesis Universität zu Köln: 353 pp.

Jungerius, P.D. \& Riksen, M.J.P.M., 2010. Contribution of laser altimetry images to the geomorphology of the Late Holocene inland drift sands of the European Sand Belt. Baltica 23 (1): 59-70.

Kasse, C., 2002. Sandy aeolian deposits and environments and their relation to climate during the Last Glacial Maximum and Lateglacial in northwest and central Europe. Progress in Physical Geography 26: 507-532.

Koopman, S., Pfeifer, A.E. \& Ruegg, G.H.J., 2010. Goois Geologisch InformatieSysteem. www.ivngooi.nl/ggis/inleid.htm.

Koopman, S. \& Pfeifer, A.E., 2012. De paleografische ontwikkeling van Gooi en Eemland sinds het Saalien. Grondboor en Hamer 3: 267-275.

Koster, E.A., 1978. De stuifzanden van de Veluwe: een fysisch geografische studie (Eolian drift sands of the Veluwe, Central Netherlands). Publicaties van het Fysisch Geografisch en Bodemkundig Laboratorium, Thesis Universiteit van Amsterdam, 195 pp.
Koster, E.A., 1982. Terminology and Lithostratigraphic Subdivision of (Surficial) Sandy Eolian Deposits in the Netherlands. An Evaluation. Geologie en Mijnbouw 61: 121-129.

Koster, E.A., 1988. Ancient and modern cold-climate aeolian sand deposition: A review. Journal of Quaternary Science 3: 69-83.

Koster, E.A., 2005a. Recent advances in luminescence dating of Late Pleistocene (cold-climate) aeolian sand and loess deposits in Western Europe. Permafrost and Periglacial Processes 16: 131-143.

Koster, E.A., 2005b. Aeolian environments. In: Koster, E.A. (ed.): The Physical Geography of Western Europe. Oxford Regional Environments. Oxford University Press: 139-160.

Koster, E. A., 2009. The history of Late Holocene drift sands in the Netherlands: origin and reactivation. In: R. Dulias, J. Pelka-Gosalciniak, \& 0. Rahmonova (eds): Ekosystemy Piaszczyste i Czlowiek. Prace Wydzialu Nauk o Ziemi Uniwersytetu Sallaskiego nr. 58, Sosnowiec: 111-134.

Koster, E.A., 2010. Origin and development of Late Holocene drift sands: geomorphology and sediment attributes. In: Fanta, J. \& Siepel, H. (eds): Inland drift sand landscapes. KNNV Publishing (Zeist): 25-48.

Koster, E.A., 2012. Sedimentologie van stuifzand. Grondboor en Hamer 65: 123-130.

Koster, E.A., Castel, I.I.Y. \& Nap, R.L., 1993. Genesis and sedimentary structures of late Holocene aeolian drift sands in northwest Europe. In: Pye, K. (ed.): The dynamics and environmental context of aeolian sedimentary systems. Geological Society Special Publication (London) 72: 247-267.

Louwe Kooijmans, L P., 1995. Prehistory or paradise? Prehistory as a reference for modern nature development, the Dutch case - Mededelingen Rijks Geologische Dienst 52: 415-424.

Louwe Kooijmans, L.P., Van den Broeke, P.W., Fokkens, H. \& Van Gijn, A.L. (eds), 2005. The Prehistory of the Netherlands. Amsterdam: Amsterdam University Press, $472 \mathrm{pp}$.

Louwe Kooijmans, L.P., 2012. Holland op z'n wildst? De Vera-hypothese getoetst aan de prehistorie. De levende Natuur, 113 (2): 62-66,

Lundström, U.S., Van Breemen, N. \& Bain, D., 2000. The podzolization process. A review. Geoderma 94: 91-107.

Madsen, A.T., Murray, A.S. \& Andersen, T.J., 2007. Optical dating of dune ridges on Rømø, a barrier island in the Wadden Sea, Denmark. Journal of Coastal Research 23: 1259-1269.

Mook, W.G. \& Van der Plicht, J., 1999. Reporting ${ }^{14} \mathrm{C}$ activities and concentrations. Radiocarbon 41: 227-239.

Moore, P.D., Webb, J.A. \& Collinson, M.E., 1991. Pollen Analysis. Blackwell Science (Malden) MA, $217 \mathrm{pp}$.

Murray, A.S. \& Clemmensen, L.B., 2001. Luminescence dating of Holocene aeolian sand movement, Thy, Denmark. Quaternary Science Reviews (Quaternary Geochronology) 20: 751-754.

Murray, A.S. \& Wintle, A.G., 2000. Luminescence dating of quartz using an improved single-aliquot regenerative-dose protocol. Radiation Measurements 32: 57-73.

Prescott, J.R. \& Hutton, J.T., 1994. Cosmic ray contributions to dose rates for luminescence and ESR dating: large depths and long-term time variations. Radiation Measurements 23: 497-500.

Pye, K. \& Tsoar, H., 1990. Aeolian sand and sand dunes. Unwin Hyman (London), $396 \mathrm{pp}$. 
Radtke, U. (ed.), 1998. Lumineszenzdatierung äolischer Sedimente. Beiträge zur Genese und Altersstellung jungquartärer Dünen und Lösse in Deutschland. Kölner Geografische Arbeiten H 70 (Köln), 124 pp.

Reineck, H.E. \& Singh, I.B., 1980. Depositional sedimentary environments, Springer (Berlin), $549 \mathrm{pp}$.

Reimer, P.J., Baillie, M.G.L., Bard, E., Bayliss, A., Beck, J.W., Blackwell, P.G., Bronk Ramsey, C., Buck, C.E., Burr, G.S., Edwards, R.L., Friedrich, M., Grootes, P.M., Guilderson, T.P., Hajdas, I., Heaton, T.J., Hogg, A.G., Hughen, K.A., Kaiser, K.F., Kromer, B., McCormac, F.G., Manning, S.W., Reimer, R.W., Richards, D.A., Southon, J.R., Talamo, S., Turney, C.S.M., Van der Plicht, J. \& Weyhenmeyer, C.E., 2009. IntCal09 and Marine09 Radiocarbon Age Calibration Curves, 0-50,000 Years cal BP, Radiocarbon 51: 1111-1150.

Riksen, M., Ketner-Oostra, R., Van Turnhout, C., Nijssen, M., Goossen, D., Jungerius, P.D. \& Spaan, W., 2006. Will we lose the last active inland drift sands of Western Europe? The origin and development of the inland driftsand ecotope in the Netherlands. Landscape Ecology 21: 431-447.

Ruegg, G.H.J., 1983. Periglacial eolian evenly laminated sandy deposits in the Late Pleistocene of NW Europe, a facies unrecorded in modern sedimentological handbooks. In: Brookfield, M.E. \& Ahlbrandt, T.S. (eds.): Eolian sediments and processes (Developments in Sedimentology 38). Elsevier (Amsterdam): 455-482.

Ruegg, G.H.J., 1995. Kwartaire wordingsgeschiedenis van, en ontsluitingen in het Gooi. Grondboor en Hamer 49: 82-89.

Schilder, M., Wallinga, J. \& Van Mourik, J., 2006. OSL and radiocarbon dating of Late-Holocene drift-sand deposits in the southern Netherlands. In: Hoek, W.H. \& Wallinga, J. (eds): NCL symposium series 4: 8-9.

Schot, P.P., 1989. Grondwatersystemen en grondwaterkwaliteit in het Gooi en randgebieden. Rapport Interfacultaire vakgroep Milieu, Universiteit Utrecht, $44 \mathrm{pp}$.

Schot, P.P. \& Engelen, G.B., 1989. Analyse van water systemen in Het GooisUtrechts stuwwallengebied, de Vechtstreek en de Eem vallei: Identificatie van knelpunten. In: Van Liere, L., Roijackers, R.M.M. \& Verstraelen, P.J.T. (eds): CHO-TNO Rapporten en Notas nr. 22: 103-117.

Schwan. J., 1986. The origin of horizontal alternating bedding in Weichselian aeolian sands in Northwestern Europe. Sedimentary Geology 49: 73-108.

Schwan, J., 1988.The structure and genesis of Weichselian to Early Holocene aeolian sand sheets in Western Europe. Sedimentary Geology 55: 197-232.

Sevink, J., 2007. Aardkundig Excursiepunt 13 Het Gooi. Grondboor \& Hamer 61: 30-35.

Sevink, J., 2010. Precisiewerk bij bodemsanering. aandacht voor venherstel en aardkundige waarden bij sanering Laarder Wasmeren. Vakblad Natuur Bos Landschap 9: 26-29.

Sevink, J., Hulshof, O.K., Mucher, H.J. \& Kroonenberg, S.B., 1970. Age and development of some fossil podzols in the Dinkel valley (E-Netherlands). In: From field to laboratory. Publ. 16, Fys. Geogr. en Bodemk. Lab. UvA: 133-148.

Sevink, J., Vlaming, M.C., Van den Berg W.J., Khodabux, E.R., Landsmeer, D. \& Stoeten, G.J., 2008. De sanering van het Laarder Wasmerengebied. Bodem 5: 8-11.

Sevink, J. \& De Waal, R., 2010. Soil and humus development in drift sands. In: Fanta, J. \& Siepel, H. (eds): Inland Drift Sand Landscapes. KNNV Publishing (Zeist) the Netherlands: 107-138.
Sevink J., Siebelink B, Strijbis P. \& De Haan F., 2012. Nieuwe schoonheid: De sanering van de Laarder Wasmeren. Waterschap Amstel, Gooi en Vecht/ Provincie Noord-Holland / GNR, 44 p.

Sparrius, L.B., 2011. Inland dunes in the Netherlands: soil, vegetation, nitrogen deposition and invasive species. Ph.D. thesis UvA Universiteit van Amsterdam, $165 \mathrm{pp}$.

Spek, T., 2004. Het Drentse esdorpenlandschap. Een historisch-geografische studie. (Village and open field landscapes of the Dutch province of Drenthe. A historical-geographical study). Thesis University of Wageningen, Stichting Matrijs (Utrecht), $1100 \mathrm{pp}$.

Strickertsson K. \& Murray A.S., 1999, Optically stimulated luminescence dates for Late Pleistocene and Holocene sediments from Nørre Lyngby, Northern Jutland, Denmark. Quaternary Science Reviews (Quaternary Geochronology) 18: $169-178$.

Tolksdorf, J.F. \& Kaiser, K., 2012. Holocene Aeolian Dynamics in the European Sand-Belt as Indicated by Geochronological Data. Boreas 41: 408-421.

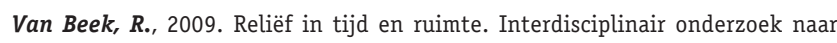
bewoning en landschap van 0ost-Nederland tussen vroege prehistorie en middeleeuwen. Ph.D. thesis. Wageningen University, 641 pp.

Van Geel, B., Bohncke, S.J.P. \& Dee, H., 1981. A palaeoecological study of an upper Lateglacial and Holocene sequence from 'de Borchert', the Netherlands. Review of Palaeobotany and Palynology 31: 367-448.

Van Geel, B. \& Bos, I., 2007. Paleo-ecologisch onderzoek naar beginnende veenvorming bij Abcoude. In: Beenakker, J.J.M., Horsten, F.J., Kraker, A.M.J. de \& H. Renes (ed.): Landschap in ruimte en tijd, Aksant.

Van Leerdam, A., Ouboter, M. \& Beemster, J., 2010. Water, de stromende verbinding tussen Eeem en Vecht, verleden en heden. Publ. Vrienden van 't Gooi / Stichting Tussen Eem en Vecht, Bussum/Naarden, the Netherlands.

Van der Meijden, F., 1996. Heukels' Flora van Nederland. Wolters-Noordhoff, $676 \mathrm{pp}$.

Van Mourik, J.M., 2003. Life cycle of pollen grains in mormoder humus forms of young acid forest soils: a micromorphological approach. Catena 54: 651-663.

Van Mourik, J.M., Wartenberg, P.E., Mook, W.E. \& Streurman, H.J., 1988. Absolute datering van humeuze horizonten in paleosolen. Netherlands Geographical Studies 74: 43-57.

Van Mourik, J.M., Wartenbergh, P.E., Mook, W.G. \& Streurman, H.J., 1995. Radiocarbon dating of palaeosols in aeolian sands. Mededelingen Rijks Geologische Dienst 52: 425-440.

Van Mourik J.M., Nierop K.G.J. \& Vandenberghe D.A.G., 2010. Radiocarbon and optically stimulated luminescence dating based chronology of a polycyclic driftsand sequence at Weerterbergen (SE Netherlands). Catena 80: 170-181.

Van Mourik J.M., Slotboom R.T. \& Wallinga J., 2011. Chronology of plaggic deposits; palynology, radiocarbon and optically stimulated luminescence dating of the Posteles (NE-Netherlands). Catena 84: 54-60.

Van Reeuwijk, L.P., 2002. Procedures for Soil Analysis, $6^{\text {th }}$ ed., Technical Paper 9. ISRIC (Wageningen), $120 \mathrm{pp}$.

Velstra, J., Van der Maarel, A.M., Heimovaara, T.J., Keizer, H. \& Taat J., 2004. Grondwateronderzoek stortplaats Anna's Hoeve en Laarder Wasmeren Complex. Royal Haskoning.

Vera, F., 1997. Metaforen voor de Wildernis - eik, hazelaar, rund, paard. Proefschrift, LU Wageningen/Ede, $426 \mathrm{pp}$.

Vos, P.C., Bazelmans, J., Weerts H.J.T. \& Van der Meulen M.J., 2011. Atlas van Nederland in het Holoceen. Bert Bakker (Amsterdam), 94 pp. 
Wallinga, J., Davids, F. \& Dijkmans, J.W.A., 2007. Luminescence dating of Netherlands' sediments. Netherlands Journal of Geosciences 86: 179-196.

Wallinga, J. \& Bos, I.J., 2010. Optical dating of clastic lake-fill sediments - a feasibility study in the Holocene Rhine delta (western Netherlands). Quaternary Geochronology 5: 602-610.

Waterbolk, H.T., 1964. Podsolierungserscheinungen bei Grabhuegeln. Palaeohistoria, 10: 87-102.

Weerts, H., Cleveringa P. \& Gouw M., 2002. De Vecht/Angstel, een riviersysteem in het veen. Grondboor en Hamer 2002 nr. 3/4: 66-71.

Whitehouse, N. \& Smith, D., 2010. How fragmented was the British Holocene wildwood? Perspectives on the 'Vera' grazing debate from the fossil beetle record. Quaternary Science Reviews 29: 539-553.

Willemse, N.W. \& Groenewoudt B.J., 2012 Resilience of Meta-Stable Landscapes? The Non-Linear Response of Late Glacial Aeolian Landforms to Prehistoric Reclamation along Dutch River Valleys. eTopoi, Journal for Ancient Studies. Special Volume 3: 1007-1037.

Wimmers, W.H. \& Van Zweden, R., 1992: Archeologische en historisch-geografische elementen in een natuurgebied : antropogene achtergronden van de Gooise natuurgebieden. Wageningen, SC-DL0 Rapport 143: 203 pp.

Wimmers, W.H., Groenman-van Waateringe, W. \& Spek, T., 1993. Het culturele erfgoed van een natuurgebied. Honderden eeuwen menselijke activiteit in het natuurlandschap van de Bussumer- en Westerheide, Historisch-Geografisch Tijdschrift 11: 53-74.

Wintle, A.G., 2008. Luminescence dating of Quaternary sediments - introduction. Boreas 4: 469-470. 